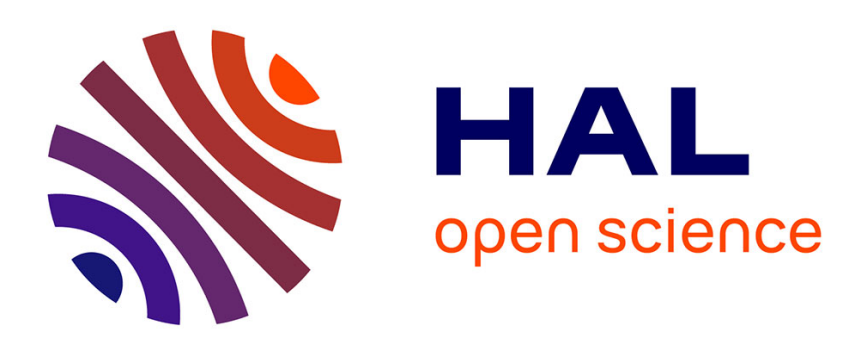

\title{
Mercantile Credit and Trading Rings in the Eighteenth Century \\ Pierre Gervais
}

\section{To cite this version:}

Pierre Gervais. Mercantile Credit and Trading Rings in the Eighteenth Century. Annales. Histoire, Sciences sociales, 2012, 67 (4), pp.731-763. halshs-01150328

\section{HAL Id: halshs-01150328 \\ https://shs.hal.science/halshs-01150328}

Submitted on 12 Mar 2017

HAL is a multi-disciplinary open access archive for the deposit and dissemination of scientific research documents, whether they are published or not. The documents may come from teaching and research institutions in France or abroad, or from public or private research centers.
L'archive ouverte pluridisciplinaire HAL, est destinée au dépôt et à la diffusion de documents scientifiques de niveau recherche, publiés ou non, émanant des établissements d'enseignement et de recherche français ou étrangers, des laboratoires publics ou privés. 


\title{
Mercantile Credit and Trading Rings in the Eighteenth Century
}

\author{
Pierre Gervais
}

On September 22, 1755, a major eighteenth-century merchant in Bordeaux, France, named Abraham Gradis ${ }^{1}$ recorded the following entry in his accounting ledger: "Salles \& $\mathrm{C}^{\circ}$ my Acct/ Dr; to Jacob Raphael his Acct £4878 our Remittances Viz. \#1000 626 at 57 at 2/U drawn this Day by Pre Taffart fils ainé On Jean Clemens and Loan of Amstd ${ }^{\mathrm{m}}$ \#1626 discounted at 57." ${ }^{2}$ His notation offers an excellent introduction to the complexity of eighteenth-century credit practices.

This article was translated from the French John Angell and edited by Nicolas Barreyre, Angela Krieger, and Stephen Sawyer.

1. Fonds Gradis, Archives Nationales (hereafter referred to as "AN"), Paris. I would like to thank the Gradis family, who granted me access to their archives. On the Gradis family, see: Richard Menkis, "The Gradis Family of Eighteenth-Century Bordeaux: A Social and Economic Study" (PhD diss., Brandeis University, 1988); Marguerite Martin, "Correspondance et réseaux marchands : la maison Gradis au dix-huitième siècle" (Masters thesis, Université Paris I, 2008); Silvia Marzagalli, "Opportunités et contraintes du commerce colonial dans l'Atlantique français au XVIII" siècle : le cas de la maison Gradis de Bordeaux," Outre-mers 362-363 (2009): 87-111; and Jean de Maupassant, "Un grand armateur de Bordeaux. Abraham Gradis (1699?-1780)," Reoue historique de Bordeaux et du département de la Gironde 6 (1913): 175-96, 276-97, 344-67, and 423-48 (on Gradis's career until 1760).

2. "Journal, 1 June 1755-26 October 1759" [Journal 1755-1759], 22 September 1755, 181 AQ 7* [Fonds Gradis], Fonds Gradis, AN, Paris. Gradis accounts for 1755 are available online, courtesy of the ANR Marprof project: http://marprof-base.univ-paris1.fr. I would like to express my sincere appreciation to Cécile Robin and Dominique Margairaz, who entered and verified the data with me. 
It states that Gradis had forwarded two letters of credit, which were drafted in Bordeaux, drawn on a firm in Amsterdam, and brokered by his Paris correspondents, Salles \& Cie. ${ }^{3}$ The letters were made out in écus de change (\#), each of which was the equivalent of 3 livres tournois (£.t.), but their value in Dutch currency had been previously negotiated ("at 57"). Gradis's Paris account was immediately credited for the corresponding value in livres tournois without waiting for the letters to be honored in Amsterdam or elsewhere. The deposit in Paris was of immediate use, since the Gradis account showed a negative balance of 22,792 £.t., seven sols (s.), and four deniers (d.) at the time, the equivalent of over $€ 130,000(\$ 168,000)$ in today's currency, or more than $€ 8$ million ( $\$ 10.4$ million) based on the average salaries at the time and compared to equivalent present-day salaries. ${ }^{4}$ Jacob Raphaël, the beneficiary of the operation, saw his own account with Gradis immediately credited for the amount that had been negotiated, either because he had brought the letters to Gradis or because Gradis decided to settle a debt to him using the income from their sale.

Only a portion of the total transaction amount reflected a material exchange of commercial paper, the balance being provided by the equivalent of a credit line on a bank account. However, these two kinds of credit were not handled identically. Salles \& Cie charged Gradis modest fees-a "commission of $1 / 3$ pr ct." and "brokerage fees of $1 / 8$ pr ct." - in exchange for receiving and brokering his commercial paper. On the other hand, Salles \& Cie appear neither to have charged interest for the credit lines they extended to Gradis nor to have paid interest for Gradis's deposits (assuming that deposits were made, since the account remained overdrawn throughout 1755). ${ }^{5}$ Furthermore, there is no evidence that interest was charged on Raphaël's account with Gradis, despite the fact that the account showed a negative balance of nearly 5,000 £.t. for the month of September 1755 . It is possible that Gradis incorporated interest charges into the credit or debit of the account when it was settled without specifically noting it in his books. The fact that he did record interest charges on a few account balances, however, tends to suggest that credit on current accounts was interest-free the rest of the time. ${ }^{6}$

In fact, references to interest on overdrafts and deposits are exceedingly rare in the records of large merchants such as Gradis as well as smaller operators,

3. A company name ending in "\& Cie" denoted a contractual partnership. See Henri Lévy-Bruhl, Histoire juridique des sociétés de commerce en France aux XVII' et XVIII" siècles (Paris: Domat-Montchrestien, 1938), 78. No further information is available on this Parisian discounting operation.

4. See the following site for values in pounds sterling: http://www.measuringworth.com/. Exchange rates are based on John J. McCusker, Money \& Exchange in Europe \& America, 1600-1775: A Handbook (Chapel Hill: The University of North Carolina Press, 1978). According to Micheline Baulant, the daily wages of a construction worker at the time was approximately 1 £.t.: see Micheline Baulant, "Le salaire des ouvriers du bâtiment à Paris, de 1400 à 1726," Annales ESC 26-2 (1971): 463-83.

5. On the Salles \& Cie account balance, see "Journal, 20 août 1751-14 mai 1755" [Journal 1751-1755], fol. 224v, 181 AQ 6*, Fonds Gradis, AN, Paris. 
shopkeepers, and craftsmen. The near-total absence of references to interest has generally been interpreted as a consequence of the Catholic Church's injunction against usury, which forbade interest-bearing loans, allowing charges only for losses incurred during currency exchanges. ${ }^{7}$ In reality, interest could be hidden in the principal of a loan, and, in any case, the injunction against interest did not in any way oblige merchants to allow customers to carry such substantial negative account balances. From the standpoint of economic rationality, the impossibility of charging interest on current-account balances ought to have provided an incentive for Gradis and his colleagues to avoid carrying unpaid debts by demanding promissory notes or other letters of credit, since comercial paper limited the duration of loans and included provisions for interest payments once loans came to term. It is also possible that they hid interest charges by recording a higher amount than the actual credit balance. However, this is inconsistent with mercantile practices of the period. Merchants made considerable advances with no evidence that they desired to charge interest and left unsettled for extended periods of time accounts that showed long-term negative balances.

It is curious types of behavior such as these that I have attempted to understand, since they send one back to a key question in economic history, namely, whether the credit practices of the early modern period foreshadowed industrial capitalism or whether they were instead founded on an entirely different logic. It has long been acknowledged that different forms of credit were fundamental to economic activity during the early modern period. Indeed, the prevalence of credit at the time has contributed to its status as one of the keys to understanding the "consumer revolution," an argument that British historiographers in particular have increasingly supported since the $1980 \mathrm{~s}^{8}$ A number of extensive monographs have paid considerable attention to the question of credit over the past thirty years: Pierre Jeannin has explored how it functioned in the Baltic region; Paul Butel, Charles Carrière, and André Lespagnol in France; Jacob Price, Kenneth Morgan, and Simon Smith in Great Britain; and David Hancock, Thomas Doerflinger, and Cathy Matson in North America. ${ }^{9}$ Each in their own way, these scholars have

7. Mark Koyama, "Evading the 'Taint of Usury': The Usury Prohibition as a Barrier to Entry," Explorations in Economic History 47-4 (2010): 420-42. Usury has been more frequently studied with regard to principles than to practice. See, for example, Norman Leslie Jones, God and the Moneylenders: Usury and Law in Early Modern England (Oxford: Blackwell, 1989).

8. Neil McKendrick, John Brewer, and John Harold Plumb, The Birth of a Consumer Society: The Commercialization of Eighteenth-Century England (London: Europa Publications, 1982); William M. Reddy, The Rise of Market Culture: The Textile Trade and French Society, 1750-1900 (Cambridge: Cambridge University Press, 1984).

9. Pierre Jeannin, Marchands du Nord. Espaces et trafics à l'époque moderne, eds. Philippe Braunstein and Jochen Hoock (Paris: Presses de l'Ens, 1996); Jeannin, Marchands d'Europe. Pratiques et savoirs à l'époque moderne, eds. Jacques Bottin and Marie-Louise Pelus-Kaplan (Paris: Presses de l'ENs, 2002); Paul Butel, "La croissance commerciale bordelaise dans la seconde moitié du XVIII ${ }^{\mathrm{e}}$ siècle" (PhD diss., Université Paris 1, 1973); Charles Carrière, Négociants marseillais au XVIII siècle. Contribution à l'étude des économies maritimes, 2 vols. (Marseille: Institut historique de Provence, 1973); André 
observed the extent to which merchants heavily relied on the networks and practices of borrowing and lending. Transactions were systematically financed either wholly or in part through credit, and participants at the time essentially operated like small banks, opening current accounts that carried negative balances and issuing their own quasi-currencies in the form of commercial paper; this commercial paper sometimes ended up circulating on a broad scale. Since most commercial operations at the time involved capital immobilization, which generated bills of exchange and other similar debts, it seems reasonable to envision the overall monetary mass of the period - to the extent that such a concept is applicable-as primarily composed of commercial paper.

Nonetheless, the importance of mercantile credit should not solely-and perhaps not even primarily-be seen as practical. According to standard economic analysis, this particular mode of credit is supposedly consistent with an idealized conceptualization of the generic act of lending based on rational individualism and maximization. During the past twenty years, a significant historiographical and theoretical movement has enriched this perspective by considering credit as an "embedded" exchange bound by specific social norms that vary according to the nature of the bond between participants. ${ }^{10}$ This embedding process, however, does not alter the nature of the credit act, defined as an immediate transfer of value, expressible in money, in exchange for a legal title that imposes a similarly monetarized transfer of value in the opposite direction at a later date, whether specified

Lespagnol, Messieurs de Saint-Malo. Une élite négociante au temps de Louis XIV (Saint-Malo: Éd. l'Ancre de Marine, 1991); Jacob M. Price, "Transaction Costs: A Note on Merchant Credit and the Organization of Private Trade," in The Political Economy of Merchant Empires, ed. James D. Tracy (Cambridge: Cambridge University Press, 1991), 276-97; Kenneth Morgan, Bristol and the Atlantic Trade in the Eighteenth Century (Cambridge: Cambridge University Press, 1993); Joseph Symson, An Exact and Industrious Tradesman: The Letter Book of Joseph Symson of Kendal, 1711-1720, ed. Simon D. Smith (Oxford: Oxford University Press, 2002); Thomas Doerflinger, A Vigorous Spirit of Enterprise: Merchants and Economic Development in Revolutionary Philadelphia (Chapel Hill: University of North Carolina Press, 1986); David Hancock, Citizens of the World: London Merchants and the Integration of the British Atlantic Community, 1735-1785 (Cambridge: Cambridge University Press, 1995); and Cathy D. Matson, Merchants and Empire: Trading in Colonial New York (Baltimore Johns Hopkins University Press, 1998).

10. Craig Muldrew, The Economy of Obligation: The Culture of Credit and Social Relations in Early Modern England (Basingstoke: Palgrave Macmillan, 1998); Margot C. Finn, The Character of Credit: Personal Debt in English Culture, 1740-1914 (Cambridge: Cambridge University Press, 2003); and Laurence Fontaine, L'économie morale. Pauvreté, crédit et confiance dans l'Europe préindustrielle (Paris: Gallimard, 2008). See also: Karl Polanyi, The Great Transformation: The Political and Economic Origins of Our Time (New York: Farrar \& Rinehart, 1944); Mark Granovetter, "Economic Action and Social Structure: The Problem of Embeddedness," American Journal of Sociology 91-3 (1985): 481-510; Marcel Mauss, "Essai sur le don. Forme et raison de l'échange dans les sociétés archaïques," L'Année sociologique special issue 1 (1923-1924): 30-186; Avner Greif, Institutions and the Path to the Modern Economy: Lessons from Medieval Trade (Cambridge: Cambridge University Press, 2006); and Robert Boyer, "Historiens et économistes face à l'émergence des institutions du marché," Annales HSS 64-3 (2009): 665-93. 
or not. The two components of credit-the period of time during which a transfer of value remains unreciprocated and its quantification, expressed in monetary terms-can potentially be analyzed outside of their particular historical context and framed in terms of a generic equivalent, meaning in solely monetary terms. Credit granted by a merchant such as Gradis can thus be read as a particular form of this generic act of credit insofar as it is bound by a certain number of imperatives that were specific to Bordeaux society in the mid-eighteenth century and which could influence a merchant's behavior, thus altering the outcome of the transaction. This specific socio-historical context, however, only defines the credit act to a certain extent and to a lesser extent than other forms that are, by definition, less "mercantile."

For these reasons, scholarly investigations of mercantile credit practices allow for a synthesis of two distinct approaches: first, a highly historicized, non-economic approach like that adopted in recent analyses of the strategies involved in the construction of relationships of trust, which explores how cultural, ethnic, and religious factors enabled such bonds to be constructed and consolidated ${ }^{11}$; and, second, a properly economic approach to the generic act of credit conceived outside of any particular historicity. Depending on each scholar's proclivity to embrace or not to embrace a teleological, optimistic perspective with regard to history, ${ }^{12}$ the generic way in which credit functioned is explained either as an outgrowth of a fundamental, ahistorical impulse of the rational human who adapted to a specific historical context or it may be attributed to the longue durée of an emergent capitalism, whose gradual development manifests itself through the destruction of the kinds of sociocultural constraints (the confiscatory power of the sovereign, religious taboos, etc.) to which a figure like Gradis was still required to submit (and from which subsequent generations of merchants gradually liberated themselves). But whatever solution is more or less implicitly adopted-whether it is grounded in a timeless impulse with different incarnations or in the gradual spread of a pluri-secular capitalist model—, the rational, maximizing individual remains at the center of the decision-making process surrounding the conduct of an economic transaction, and "embedding" the process within social and cultural contexts does not change the transparency of the actors' motives: Gradis was seeking no more and no less than to clear a profit.

11. Silvia Marzagalli, "Establishing Transatlantic Trade Networks in Time of War: Bordeaux and the United States, 1793-1815," Business History Review 79-4 (2005): 81144; David Hancock, Oceans of Wine: Madeira and the Emergence of American Trade and Taste (New Haven: Yale University Press, 2009); Jacob M. Price, Overseas Trade and Traders: Essays on Some Commercial, Financial and Political Challenges Facing British Atlantic Merchants, 1660-1775 (Aldershot: Variorum, 1996); and Francesca Trivellato, The Familiarity of Strangers: The Sephardic Diaspora, Livorno, and Cross-Cultural Trade in the Early Modern Period (New Haven: Yale University Press, 2009).

12. In English-language historiography, this is called "whig" history, modeled on what Herbert Butterfield criticized in The Whig Interpretation of History (New York: W. W. Norton \& Co, 1931; repr. 1965). See also Nick Jardine, "Whigs and Stories: Herbert Butterfield and the Historiography of Science," History of Science 41-2 (2003): 125-40. 
As Alessandro Stanziani has asserted, there are high epistemological costs for so uncritically redeploying a concept borrowed from the field of economics. ${ }^{13}$ By imposing an analytical framework that presupposes the "economic" rationality of a figure like Gradis - a rationality constructed outside of his universe and unconnected to other elements of his society-scholarly insight is deeply constrained, and the workings of the historical specificity of an agent's acts are relegated to the background. This is why I propose an analytical inversion of this approach that examines the fully historicized microeconomics of credit in the early modern period and posits it as fundamentally different from the notion of credit that arose within the framework of industrial capitalism over at least the past 150 years. Other scholars have also adopted this perspective, including Jean-Yves Grenier, who has proposed modeling the economy of the Old Regime in a specific way because it was articulated around cycles of exchange that constituted the principal locus of creating and sharing profit, with mechanisms such as production (costs) and consumption (supply and demand) operating only as secondary to the central process. Similarly, Guillaume Daudin's attempt to create a model of a segmented Old Regime market and its implications with regard to determining profit margins, leads to aggregate mechanisms that are qualitatively different from those of standard economics. The idea of reintroducing a systematic-rather than simply contingent-heuristic border between the early modern period and contemporary capitalism also frames the work of scholars such as Dominique Margairaz and Maxine Berg. ${ }^{14}$

There is, however, a significant obstacle to rethinking the distinction between mercantile credit and capitalist credit in that microeconomic analysis does not enable a clear distinction to be drawn between the two kinds of credit. In principle, credit is credit, regardless of the historical period. It is precisely this obstacle that I propose to overcome. Instead, I would like to posit the hypothesis that it is possible to draw on analyses of the two historical sources produced by early modern merchants - their correspondence and accounting records-by focusing on the traceable transactional practices of the period, observable constraints on payments and transfers of value, and how these operations were analytically recorded in accounting systems, in order to arrive at an interpretation of eighteenthcentury credit that is purely local in terms of both period and region but that does not abdicate systematic analysis. This interpretive approach represents the best antidote to the occasionally implicit assumption by numerous scholars of externally

13. Alessandro Stanziani, "Information, institutions et temporalité. Quelques remarques critiques sur l'usage de la nouvelle économie de l'information en histoire," Revue de Synthèse 121-1/2 (2000): 117-55.

14. Jean-Yves Grenier, L'économie d'Ancien Régime. Un monde de l'échange et de l'incertitude (Paris: Albin Michel, 1996); Guillaume Daudin, Commerce et prospérité. La France au XVIII siècle (Paris: Presses de l'université Paris-Sorbonne, 2005); Dominique Margairaz, "Économie et information à l'époque moderne," in L'information économique XVI ${ }^{e}$ XIX siècle. Journées d'études du 21 juin 2004 et du 25 avril 2006, eds. Dominique Margairaz and Philippe Minard (Paris: Comité pour l'histoire économique et financière de la France, 2008), 3-16; and Maxine Berg and Pat Hudson, "Rehabilitating the Industrial Revolution," Economic History Review 45-1 (1992): 24-50. 
defined rationality. Furthermore, it enables the construction of a valid approach to microeconomic decision-making that respects the observable motivations of agents. In one sense, this entails reviving the Marxian notion of modes of production, ${ }^{15}$ defined as the particular rules of a given time and place that govern the division of labor and hence the survival, reproduction, and expansion of human groups whose members accept and apply these rules. As described in this essay, credit appears to be emblematic of the ways in which western European societies of the early modern period and their colonial outposts were constructed in economic terms; the rules and the ways in which credit in this very general sense operated in these zones at the time differentiated these societies from neighboring societies, which were organized according to different principles.

\section{Credit, Specialization, and Trading Rings}

An understanding of how credit functioned in the early modern period is necessarily grounded in what the notion meant to its users. The "credit" sought by a merchant encompassed far more than a mere loan balance. Before becoming the quantifiable measure of a monetary advance, credit first manifested itself through trust in the other, a "confidence" defined as the "assurance that one can develop on someone's probity and discretion." 16 It centered on a relationship between two individuals based on mutual trust born of the fact that each interlocutor acted according to a set of tacit but consensually agreed-upon rules, among them that they would never break these rules solely to pursue their own purposes. ${ }^{17}$ This respect for rules does not mean that the actions of one's interlocutors were systematically benevolent, but that his or her actions could be predicted with relative certainty once the rules were known. One extended credit to someone to the extent that he or she was expected to act according to the rules that governed this particular relationship. Credit, in this specific sense, was the basis of the mercantile transaction.

The universality of this credit relationship is relatively easy to establish by breaking down a typical eighteenth-century transaction into its constituent parts.

15. As suggested by Guy Bois, "Marxisme et histoire nouvelle," in La nouvelle histoire, ed. Jacques Le Goff (Bruxelles: Éd. Complexe, 1978; repr. 2006), 255-74.

16. Dictionnaire de l'Académie française (Paris: $\mathrm{V}^{\mathrm{ve}}$ de B. Brunet, 1762), 363. "Confidence" here is therefore not understood in the same way as in the field of sociology, which is relatively vague and ahistorical: see, for example, Philippe Aghion et al., "Regulation and Distrust," The Quarterly Journal of Economics 125-3 (2010): 1015-19. The authors apply the same term to each instance in which the good intentions of an interlocutor are asserted, regardless of his or her nature and intentions.

17. One's word of honor can therefore not be reduced to a combination of the components of standard economic analysis such as information and sanction, contrary to Timothy W. Guinnane's assertions: see Timothy W. Guinnane, "Trust: A Concept Too Many" (Economic Growth Center Discussion Paper no 907, Yale University, 2005), http://www.econ.yale.edu/growth_pdf/cdp907.pdf. 
For every purchaser of goods, the commercial exchange relied first on consistency between the apparent quality of the goods, as manifested in its position within a given price range, and its actual quality. This consistency was not at all certain. Who could confirm that a lot of woolen cloth was what it appeared to be-whether or not it contained hidden flaws, whether the lead seal reflecting its origin was counterfeit or whether its weight, fabrication, or size were truthfully represented? ${ }^{18}$ Even sellers were often unable to offer such assurances, since they too relied on the honorable word of their own sources, a sequence of assumptions rooted in trust that stretched across the chain of distribution all the way back to the weaver or even the shepherd who raised the sheep. A buyer who had been cheated could attempt to sanction dishonest behavior after the fact by attacking the reputation of the guilty party, but this was not very effective in the case of a transitory relationship. Sellers faced a parallel problem involving information, since a sales strategy and a particular clientele—in effect a market segment—corresponded to a given quality, which provided the basis for setting prices. Moving merchandise implied identifying and penetrating the segment of the market that was best adapted to the product and yielded the best price. In a sense, the quality of the product corresponded to the quality of the market, which was the guarantee of the highest possible selling price. ${ }^{19}$

Specialization could provide a solution to this two-fold problem. It allowed the purchaser to develop the experience needed to provide an informed assessment of the merchandise, and the seller was able to acquire sufficient knowledge of a particular market to be confident of the best possible return. But this solution had significant costs because focusing on either a single product or a narrow range of products reduced the diversification of risk that was indispensable in segmented, highly volatile markets, and acquiring adequate knowledge required considerable effort, given the infinite variety of nomenclatures during the early modern period. Furthermore, it did not constitute an absolute guarantee: even experienced vendors of simple products like flour could be cheated..$^{20}$ Ultimately, hyperspecialization represented an exception that only made sense for highly specific commercial branches. For this reason, seemingly specialized traders operated in reality across a relatively wide range of products. In 1788, the Philadelphia trader Levi Hollingsworth, a Quaker and colonial notable and an officer under George Washington (who left even more complete archives than Gradis), was so specialized in flour that he maintained a separate accounts ledger for flour that he sold on commission. However, he scrupulously maintained accounts for no fewer than eleven other products in addition to accounts for "Dry Goods" and "Merchandize," which encompassed a wide range of products. ${ }^{21}$

18. Jeannin, Marchands d'Europe, 309-20. See also Gérard Béaur, Hubert Bonin, and Claire Lemercier, eds., Fraude, contrefaçon et contrebande de l'Antiquité à nos jours (Genève: Droz, 2006).

19. Alessandro Stanziani, ed., La qualité des produits en France, XVIII ${ }^{e}$-XXe siècles (Paris: Belin, 2003); Grenier, L'économie d'Ancien Régime.

20. Examples can be found in Matson, Merchants and Empire, 237-40. 
Thus, the most common solution to the two-fold problem of gleaning information about the product and information about the market was not specialization, but rather the delegation of decisions to carefully chosen factors. The problems of assessing both the quality of the product and the target market were entrusted to the best-placed individual with regard to the necessary information. For example, a Boston importer specialized in English textiles named Nathan Appleton sent the following instructions to his brother in London in 1813 (apparently hoping for a rapid conclusion to the War of 1812):

\begin{abstract}
I should like however to have some good merchandize for me should they be reasonably low. Say to am(t) of $£ 5000$ - if you have not already purchased any for you M. Stone is an excellent judge of goods + I should like to have you get him to purchase them if you do not wish to do it yourself - I have about £2500 I suppose in Lodges + [Prother?] hands-but [ill.] they will be glad to accept drafts to a greater am(t)—whilst the goods are in their hands. It is [also?.] necessary that I should give a particular order as I wish the goods to be of the most staple kinds say Cambrics Calicoes shirtings ginghams $+c$. to am(t) of $£ 3000$ or $4000-+1$ or $£ 2000$ in staple woolens as in my former letter [pr?] $I+T$ Haigh for goods in their line - I leave it however to your judgement from the state of the market + the prospect of peace or a continuance of the war to purchase or not at all. ${ }^{22}$
\end{abstract}

To order merchandise in England, Appleton relied on a certain M. Stone and-to exert a degree of control over Stone-his brother, despite the fact that he was highly specialized and qualified to judge his own purchases. Although he had specific ideas about what he wished to acquire, he made a point of deferring to his correspondents' judgment, whom he considered better placed to evaluate whether a particular fabric provided an acceptable quality-price ratio, within certain general limits that his familiarity with the Boston market enabled him to establish.

Nathan Appleton also delegated the selection of the actual stock, which gives some indication of the level of confidence that buyers must have accorded to suppliers at the time. Given the delays involved, overly precise instructions were probably pointless in any event, since by the time an order arrived, the structure of the Boston market would have had time to undergo several changes. It was better to rely on the supplier to propose a product with a good quality-price ratio. Nathan Appleton, for his part, took care in choosing the most propitious time to sell. The temporality of a given market played a critical role in prices, which were dependent on the timing of the sale within a partly fixed annual pricing cycle. In effect, the principal was compelled to rely entirely on his or her factor, a point often referred to in period sources.

22. Nathan Appleton to Samuel Appleton, 17 September 1813, Box 2: "General Correspondence, etc. 1791-1814,” Folder 25: “1813,” Ms. N-1778, Appleton Family Papers (hereafter referred to as "Appleton Papers"), Massachusetts Historical Society, Boston. I already cited this example in Pierre Gervais, "Neither Imperial, Nor Atlantic: A Merchant Perspective on International Trade in the Eighteenth Century," History of European Ideas 34-4 (2008): 465-73. 
Nathan Appleton enjoyed a rare privilege insofar as his brother, who resided in London, was both devoted to his interests and capable of correctly evaluating demand in the target market, the northeastern United States, a fact acknowledged in the following compliment: "Most of the goods you sent out this year were very well suited to [our] market." 23 "Well suited" referred to a quality that corresponded to a client's expectations. The client would consequently be disposed to pay a price that permitted a substantial 50 and $100 \%$ gross margin. The near-complete lack of reference to specific prices in the correspondence of the period is striking and reflects the fact that calculating the real costs of a particular trade item (transportation, stocking, and diverse fees included) was not considered a priority. To guarantee a final profit, the selling price could be calculated by simply multiplying the purchase price by $150-200 \%$. A product that "sold poorly" was a product for which there were no buyers at a particular price point and which was ultimately sold at a loss, even if-like profit-losses were rarely calculated. The clientele's tastes were obviously taken into account, ${ }^{24}$ but the principal variable remained the quality-price ratio, which-in the same way as a product's physical properties-was considered a quality. A competent buyer like Samuel Appleton was able to obtain a certain level of quality within a certain price range that corresponded to the expectations of a particular clientele. This cluster of prior decisions established the scale of the final profit, which ultimately depended as much on the supplier as on the merchant who made the final sale.

Each individual transaction thus represented an act of mutual trust for the buyer and the supplier, which can be summarized thus: I am selling you what I say I am selling you, and you give me the best possible price at a given moment and in a given place for the quality being offered. The relationships that were established through these exchanges tended to be long-lasting, since punishing incidences of cheating by attacking the guilty party's reputation was effective only in the context of a long-term relationship. Because of this, there was risk involved in committing oneself to short-term relationships. New or chance commercial encounters were, by nature, speculative and could therefore not represent more than a small proportion of the exchanges of any reasonable operator. Jeannin has calculated that over a period of twelve years, between 1763 and 1775, the Bordeaux firm of Schröder and Schyler regularly dealt with only seventeen foreign firms. Although 250 other firms also appeared either as customers or as suppliers, $47.8 \%$ of the products shipped by Schröder and Schyler were sent to this core group of seventeen firms. ${ }^{25}$

23. Nathan Appleton to Samuel Appleton, 6 February 1813, ibid., Appleton Papers.

24. Hancock, Oceans of Wine.

25. Pierre Jeannin, "La clientèle étrangère de la maison Schröder et Schyler de la guerre de Sept Ans à la guerre d'indépendance américaine," in Marchands d'Europe. Pratiques et savoirs à l'époque moderne, eds. Jacques Bottin and Marie-Louise Pelus-Kaplan (Paris: Presses de l'ENS, 2002), 125-78. For an effective analysis of how information circulated at the time, see Silvia Marzagalli, "La circulation de l'information, révélateur des modalités de fonctionnement propres aux réseaux commerciaux d'Ancien Régime," Rives méditerranéennes 27 (2007): 123-39. 
Such a high degree of market concentration had significant ramifications. Mercantile networks have been described by recent historiographical studies as comprised of a group of relationships that were not highly hierarchical and were even configured in the pattern of an undifferentiated star or an interconnected web. In fact, these relationships functioned as a substitute for specialization, meaning that those involved operated only in individual segments of the market and that each "network" constituted a specialized group. The accounts the Bordeaux shipper Gradis opened for others corroborate this. I extracted data from Gradis's accounting records for the year 1755 and concerning compensations between two personal accounts, excluding the shipping partnerships. I considered that these direct compensations from one personal account to another revealed both a degree of proximity between the holders of both accounts and Gradis's decisive role in their relationship. This does not imply that two accounts not displaying any interaction between them for the span of a year belonged to two individuals who did not themselves interact, but the absence of interaction between both accounts rules out the possibility of a triangular relationship between the two account holders and Gradis, who would in that case have maintained separate relationships with each of them. If one considers each compensation as a link between the two accounts, and the total value of the compensations as an indicator of intensity, one arrives at figure $1 .^{26}$

The data confirms that the Gradis accounts should be understood as a series of discrete sub-networks that existed in relative isolation from each other. They also illustrate the importance of the shipper's Canadian activities, which are consistent with his role as the official supplier of the province of Quebec, both in terms of the significant share of the total value of the compensation from his Canadian exports and the prominence of the "Canadians" who figured among his business partners: François Bigot (the intendant of Canada), Michel Péan (Aide-major of Quebec), and the Quebecois traders Charles-François de La Naudière and Guillaume Estèbe formed a group that completed that of Gradis's principal allies in France, Nicolas (?) Luker de Nantes, the firm Horutener \& Cie in Rouen and, in Bordeaux, the notary Jean Perrens, a certain Dupin (probably François Dupin des Lèzes, secretary to the intendant Tourny), and the trader Jean Leris.

Figure 1 also indicates the simultaneous existence of several other networks, which were either not at all or only slightly interconnected or linked to the principal network and whose cumulative importance was relatively significant. The block of accounts labeled "Prunes" is a relic of the division of the "Prunes Frères" account between its two holders, but other compensations were also significant, among them activities conducted in Cadix through the intermediary efforts of

26. I exclude account closings and the transfer of value between two accounts referring to physical assets belonging to Gradis himself, for example "Marchandises pour la Cargaison $n^{\circ} 7 \mathrm{dt}$. à Marchandises générales." When there is a doubt (which is the case with Cargo $\mathrm{n}^{\circ} 7$, which could have belonged to a partnership of which Gradis was a member), the entry has not been used. Gradis's account with Chabbert \& Banquet, who served as a discounting bank for Gradis, is considered a treasury account. 
Figure 1. Interactions Between Personal Accounts in Gradis Firm Accounting (1755)

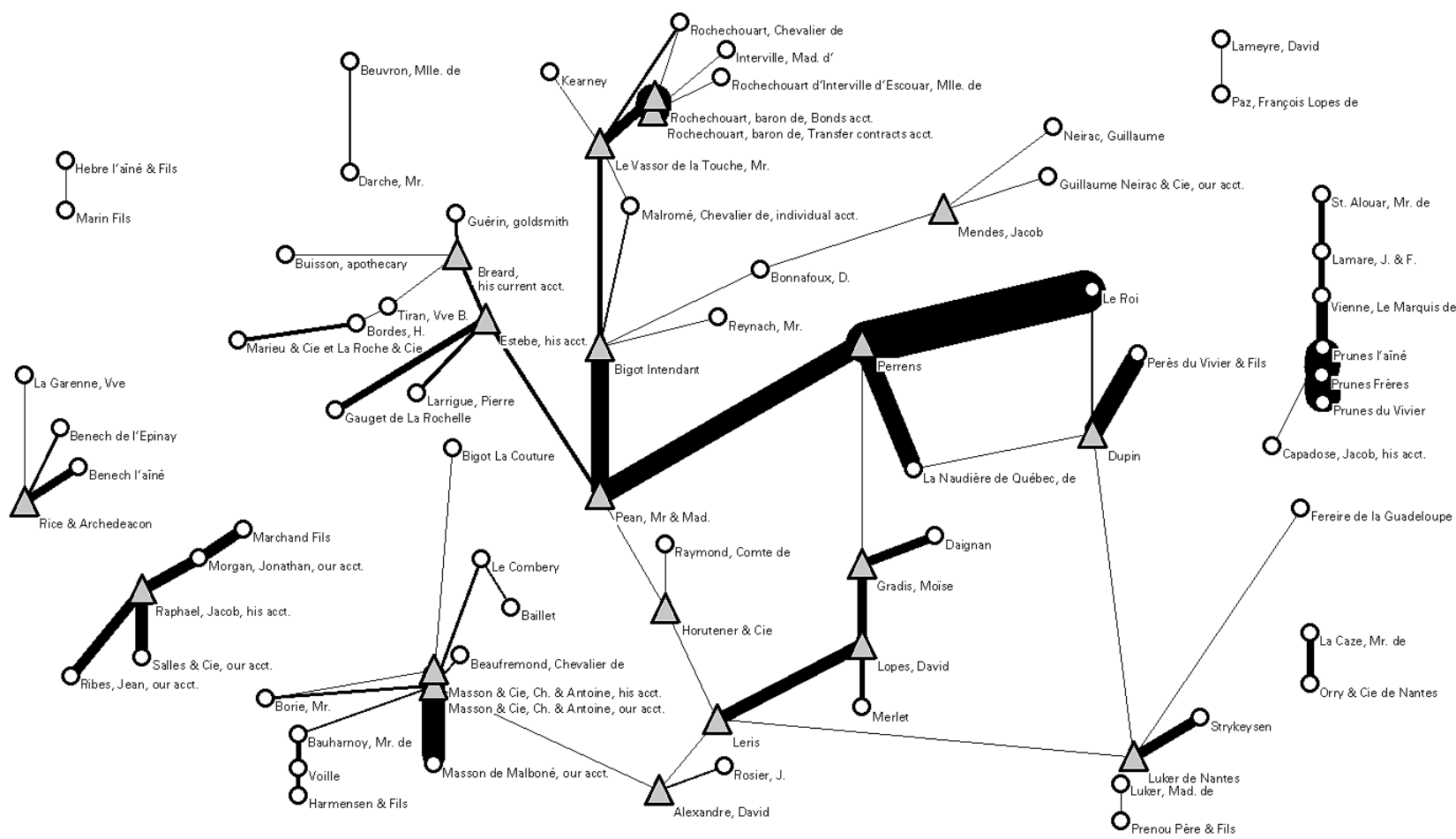

Source: Journal 1751-1755 and 1755-1759, 181 AQ 6* and 7*, Fonds Gradis, AN, Paris. Out of 269 personal accounts (excluding ship-related accounts), eightythree connected to at least one other account are represented. The gray triangles represent nodal accounts, meaning accounts or combinations of accounts linked to at least three other personal accounts. The width of the link corresponds to the value exchanged (for example, 83,030 £.t. between "le Roi" and "Perrens," 4,724 £.t. between "Bigot Intendant" and "Mr. Le Vassor de la Touche"). 
Charles and Antoine Masson. This is all the more true since certain links that appeared connected to the principal network may very possibly be related to nonCanadian activities. The link between Jean Leris and David Lopes is described in the following notation: "Leris Dr. to David Lopes $\$ 12027$ pr a Note of said Lopes dated March 19 p.ble July 21 last which we refund to said Lopes." The considerable sum that was transferred was not necessarily related to Canada, however, even if Leris was a full participant in the Canadian expeditions. ${ }^{27}$

The initial picture this provides confirms that Gradis's activities were organized around sub-networks, with each one revolving around one or two important figures. The obvious cohesion of the groups attests to the fact that this impression is not an accident but one that reflects true relationships. The powerful subnetwork that Gradis developed in Canada is highly visible and easily differentiated from other sub-networks-for example, Gradis's export activities toward northern Europe, which were directed through Jonathan Morgan of Cork or Jacob Raphaël, whose operations were connected to Amsterdam. Within each sub-network, much like the overall network, there was a strong hierarchy but weak interconnections. Each sub-network was essentially comprised of a series of divergent chains instead of being connected through multi-directional strands, as some historiographical accounts have suggested. This is confirmed by analyses of several trade items with sufficient importance among Gradis's activities to warrant dedicated accounts. These items were divided into three groups that seemingly have little in common with each other: flour; wine and brandies; and colonial products such as coffee, indigo, and sugar. Gradis had built up a specific network for each of these families of products (see figure 2).

The fact that only five of the approximately 220 individuals mentioned in the Gradis accounting ledgers were directly linked both to the wine and spirits market and colonial products confirms this analysis. The majority of this small group of interlocutors were close partners. One of them was Moïse Gradis, Abraham's nephew and a member of the firm. The account labeled "Alexandre" refers either to Samuel Alexandre, a former associate of Abraham Gradis's father and the husband of his sister Rachel, or to his son (and hence Gradis's nephew) David Alexandre, who was based in Bayonne. David Lopes was a close relative as well, either a family member (Abraham Gradis's sister had married a certain Louis Lopes-Depas, a landowner in Saint-Domingue) or the son of Aaron Lopes, a fellow Bordeaux shipper. ${ }^{28}$ Specialization was also evident in the network's nodal accounts around which personal sub-networks were organized (see figure 1). The key actors in these sub-networks were themselves also restricted to a particular sub-section of the

27. Journal 1755-1759, 10 November 1755, Fonds Gradis, AN, Paris. On Leris's involvement with Canada, see the entries for March 4, 20, and 31, in addition to April 23 and 24, 1755, which note his participation in the embarcation of the ships La Renommée and Le David as well as "Cargo $\mathrm{n}^{\circ} 7 . "$

28. Martin, "Correspondance et réseaux marchands," 136; Jean Cavignac, Dictionnaire du judaïsme bordelais aux XVIII et XIX' siècles : biographies, généalogies, professions, institutions (Bordeaux: Archives départementales de la Gironde, 1987), 41 and 152. 
Figure 2. Accounts of Individualized Products and Their Users in Gradis Firm Accounting Ledgers (1755)

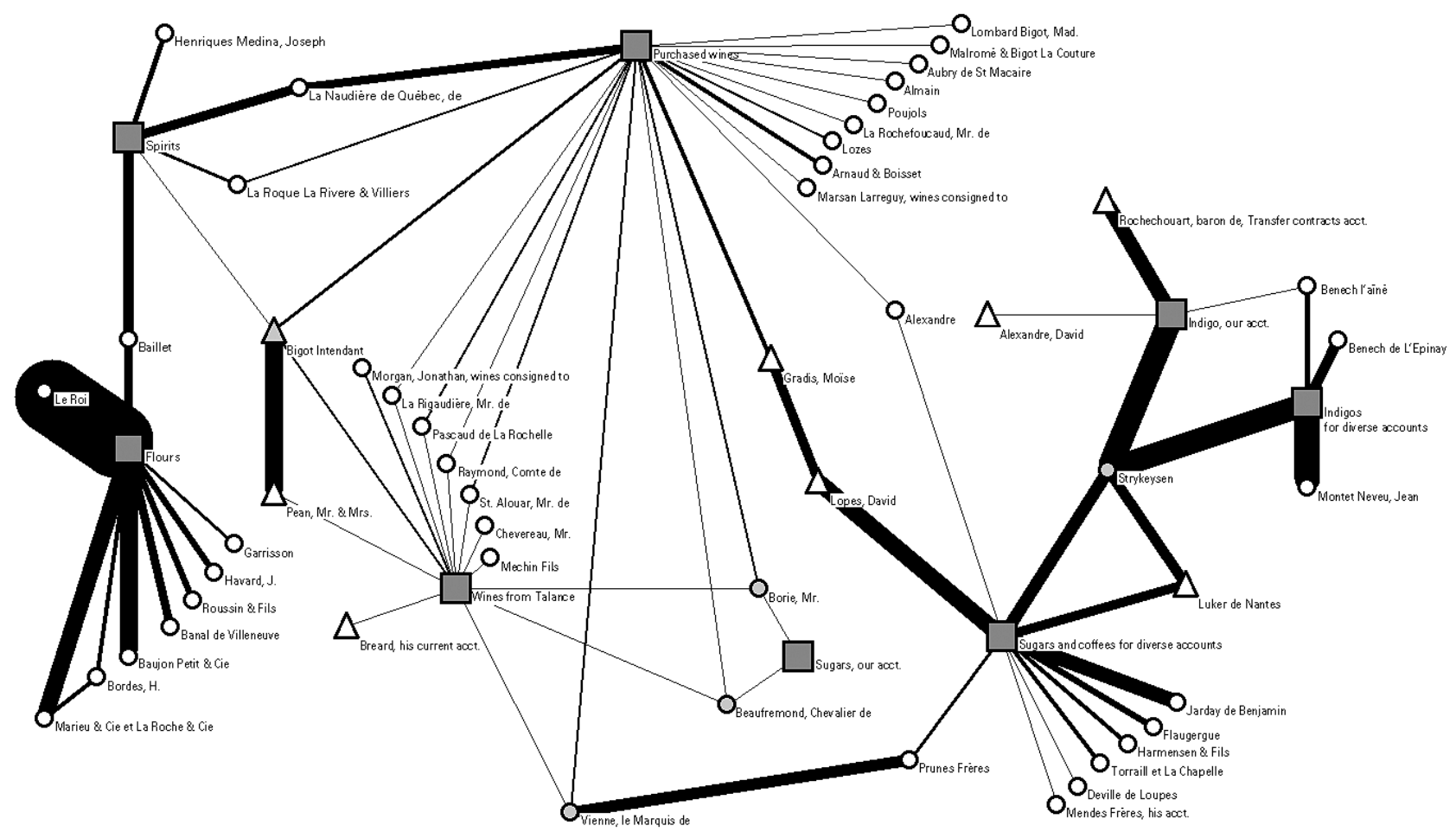

Source: Journal 1751-1755 and 1755-1759, $181 \mathrm{AQ}$ 6* and 7*, Fonds Gradis, AN, Paris. I have not included general merchandise or cargoes, which were, by definition, supplied by numerous different networks. Triangles indicate nodal accounts from Figure 1, and dark gray indicates an actor linked to at least three trade items. Three accounts (Campeche Wood from our acct., Sugars, and Raw Sugar) have no connections to the personal accounts of 1755 . The spelling is Gradis's (for example, "Talance" instead of "Talence"). 
Gradis firm's overall activities. None of these key accounts appears to be tied to two different products, with the exception of Bigot, the intendant of Canada, who invested in wines and spirits. But even he is not mentioned as having participated in operations involving flour or colonial products from the French island possessions.

Not all merchandise flowed through dedicated accounts, of course, and Bigot did occasionally purchase flour, as the following entry illustrates: "Mr Bigot Intendant Dr ... Pr. amount of goods Loaded on his Account \& Risk in the Ship La Renommée Capt. J. Rozier for Quebec, for which we Gave him our Receipt at Rochefort on the Currt. Viz. To General Merchandize for various supplies From Baas £1254.2 For 100 Barrels flour from Neirac 2496.17.6 4 For 4 Crates Candls 1528.9 For lard 633 For Jam 458.2.6." 29 However, this flour purchase appears to be the only one in which Bigot participated in the year 1755, whereas during the same period, he placed no fewer than four orders with the same supplier for significant quantitities of wine and brandy. Conversely, there is no evidence that Bigot speculated on colonial products (with the sole exception of a shipment of sugarloaves that were shipped at the same time as the barrels of flour). He evidently limited most of his activities to a narrow range of products, mainly wines and spirits but occasionally including lard and oil, as well as a selection of luxury items for his personal consumption. As a courtesy account intended to preserve the goodwill of the colony's intendant by compensating him, a greater degree of diversity in the activities of the Bigot account would have been quite justified. But its limited range demonstrates that, on the contrary, the apparent specialization of the Gradis network is no illusion, since it applied to the official executive of Quebec as much as it did to other actors. Suppliers and buyers were enclosed within specific product domains, each with its own figures, logic, rhythms, and history. For this reason, the term "rings" is clearly more accurate than "networks" and will be the preferred term throughout the rest of this article.

By simply observing the discontinuities between different rings, it should be possible to triangulate between several accounting archives to reconstitute this array of segmented markets. The fact that many of those involved participated in two markets or in the markets for well-defined clusters of different products suggests that similar expertise could be applied to more than one market context. With respect to Gradis, for example, the shared expertise of participants in markets in the "wine" category was not solely limited to wine, but also applied to both wine and spirits produced in the Bordeaux hinterland. In this sense, spirits from the Charente region and wines from Graves or Talence belong to the same category of products, which did not, however, encompass wines and spirits in general. For obvious historical reasons, Burgundy wines or spirits from Madeira, for example, involved very different knowledge bases and therefore distinct trading rings from Bordeaux wines. From this perspective, the early modern era was notable for hyperspecialization among merchants, which leads one to wonder whether later, nineteenthcentury trends toward "specialization" actually represented an intensification of 
this earlier pattern. Maybe these trends should instead be considered as resulting from profound changes in how specialization itself was constructed. While, in the eighteenth century, specialization was the result of highly regionalized markets, themselves the product of a high level of path dependency generated by particular historico-institutional contexts, the new type of specialization that emerged in the nineteenth century could be described as being based on generalizable market norms on an intercontinental level.

These observations could provide the basis for an understanding of the segmentation of early modern markets. Segmentation did not operate directly on a given product, but rather through the development of specializations among groups of traders in certain products that were ultimately bound within the same market by the community of experts and the transactions that these groups generated, beyond a simple process of definition within product nomenclatures. Such a mercantile community constituted a "ring" that drew its cohesiveness not only from the specificities of the production process of the product in which it dealt, but also from the social and geographical origin of the producers, the organization of distribution networks, and other factors. This structure was self-reproducing, since after such segmented rings became established, it became extremely difficult for outsiders to enter the markets due to the high level of solidarity between the principal operators. In reality, seemingly "free" markets were, if not completely cartelized, at least dominated by a small group of operators who derived significant profits from their domination. Thus, credit networks can be seen as outgrowths of particular mercantile rings, each focused on sharing and controlling market segments, along the same lines of what I have observed on the East Coast of the United States during the early nineteenth century. ${ }^{30}$

\section{Credit Tools and the Regulation of Transactions}

Within the framework of more or less formalized associations organized in such a way as to constitute rings controlling particular markets segments, credit relationships-understood in the broad sense of mutual credit-constituted the building blocks of effective management of both the flow of merchandise and the market segments on which this merchandise would end up being sold. This is all the more true in that the proper functioning of these rings over time depended on the other component of the mercantile transaction: payment. Indeed, the amount of actual gold and silver coinage typically involved in mercantile exchanges was relatively small, and most payments were made through compensation or commercial paper. Free, informal credit corresponding to a negative balance in a particular account was a crucial ingredient in such payments, an indication of the profound economic interdependency between members of a particular trading ring. Opening an account with a client or supplier was tantamount to providing access to free credit and, up 
to a certain point, constituted a partnership of which the beneficiary was obliged to enter into reciprocal credit arrangements, either directly via an account-if the account oscillated between a positive and negative balance-, by proxy through other accounts, or even through a game of in-kind exchanges that were not recorded in accounting systems but which functioned "as payment" for shared lucrative operations. In the latter case, compensation could include the exchange of useful information or personal services rendered on the side. From this perspective, managing an account considerably depended on the broader context and involved the economic context of the ring in question and the place of each interlocutor within it in addition to the social and institutional context of the bond between participants created by the transaction, which could include a multitude of elements that were not, strictly speaking, economic in nature.

To illustrate this argument, consider the example of four accounts reflecting significant, even very large, negative balances or debts to Gradis in the summer of 1755. The Bordeaux notary Jean Perrens owed nearly 80,000 livres. Another Bordeaux account, the fittingly named Marchand Fils, owed 25,000. Bigot, the intendant of Canada, owed 43,000 livres. In contrast, the widow La Roche from Girac owed the comparively modest sum of 842 livres (which nonetheless amounted to three years of a laborer's wages at the time). Each of these accounts had its own separate history. The intendant Bigot's account, for example, was periodically credited for large sums that reflected his share of the profits made by Gradis on supplies for the province; the account was debited nearly every week for sums that varied according to Bigot's expenditures. A portion of Bigot's revenues was normally transferred to Gradis's account with his Parisian bankers, Chabbert \& Banquet, to compensate for the intendant's expenditures, but in the summer of 1755, he had also drawn directly on the Parisians, thus spending the funds that were supposed to finance Gradis's advances. The Marchand Fils debt, on the other hand, was quite different. It involved a fellow Bordeaux shipping agent and trader who was also one of Gradis's principal partners in investment groups constituted to outfit and charter the ships Le Sagittaire, Le Président Le Berthon, and La Reine Esther. The two entries concerning a 23,000 livre debit received from Gradis in the summer of 1755 undoubtedly corresponded to an investment by Marchand Fils in one of Gradis's adventures, for which Gradis was responsible for transferring funds as needed to the account of the particular adventure in question. ${ }^{31}$ The Perrens account, on the other hand, reflects a structural deficit that is reflected in his statement of account dated December 10,1754, which provides an overview of nine months of activity (see figure 3 ). In reality, however, the deficit was an advance that was part of a well-defined partnership, despite the fact that the relationship probably did not involve a written contract, as opposed to outfitting and shipping services

31. And not to his investment in Le Sagittaire, as I erroneously asserted in Pierre Gervais, "A Merchant or a French Atlantic? Eighteenth-Century Account Books as Narratives of a Transnational Merchant Political Economy," French History 25-1 (2011): 28-47. This investment had been credited to Marchand Fils on October 29, 1754, and reimbursed by letters of exchange from Gradis on February 19 and March 19, 1755. 
Figure 3. Movements of the "Perrens" Account With the Gradis Firm (1755)

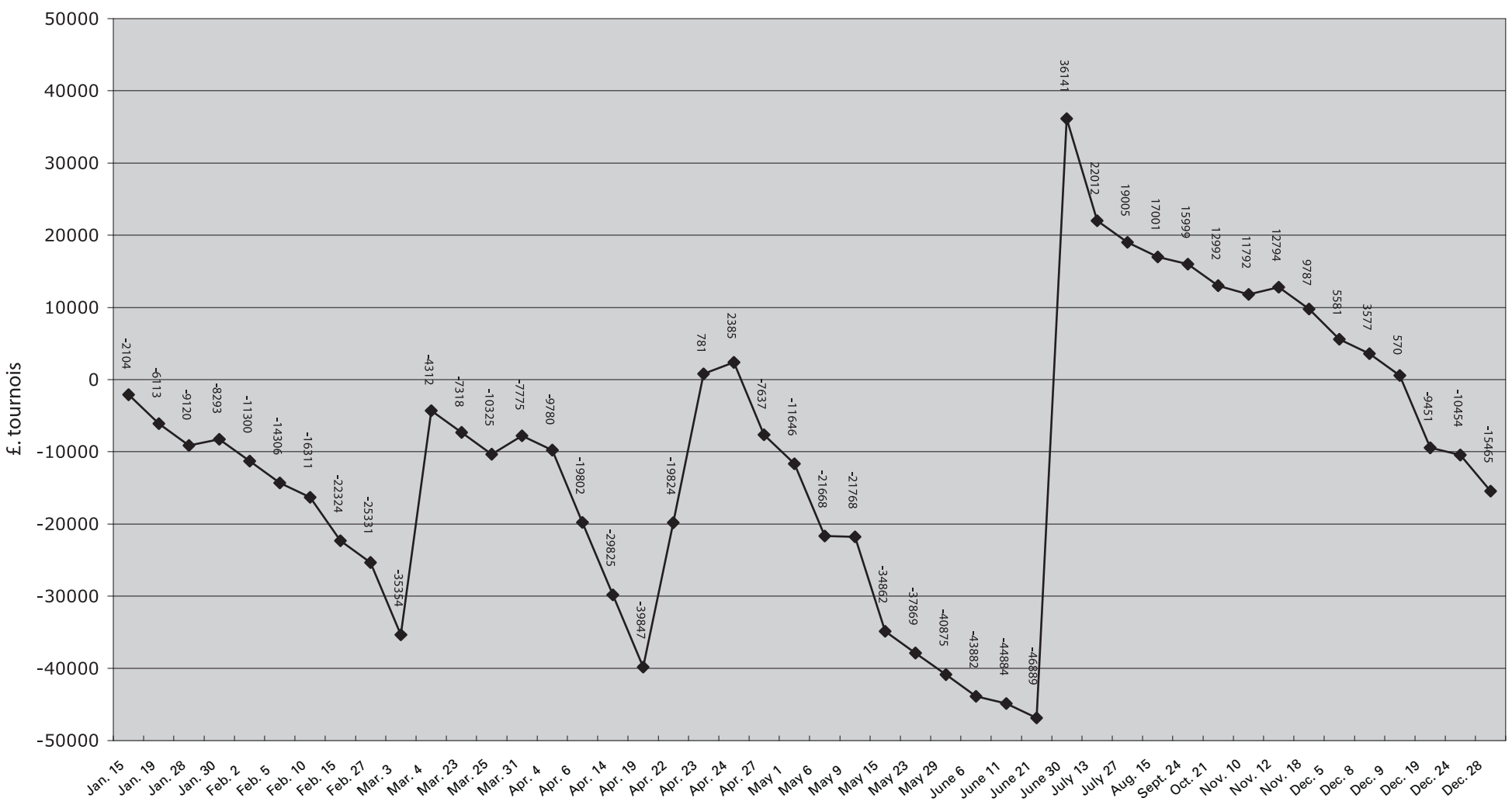

Sources: Journal 1751-1755 and Journal 1755-1759, 181 AQ 6* and 7*, Fonds Gradis, AN, Paris. The figures correspond to the balances of operations since the first entry and not to the true account balance, which is unknown because the account remained open during the period studied. 
conducted in partnership with Marchand. Gradis regularly advanced the necessary funds for the notary to acquire considerable quantities of merchandise as cargo for Canada, including flour, lard, salt, and brine. Thus, the advances to Perrens were effectively advances to the King, for which Perrens functioned as Gradis's supplier in the region. The widow's account reflected yet another set of circumstances: Gradis claimed the sum of 842 livres as a balance due to him for settling her late husband's affairs (he was one of Gradis's former business relations).

Each of these debts had been accumulated in a different context and was consequently handled differently. It is not known whether Bigot's negative balance was a brief mishap or a structural deficit, but Gradis would never have refused advances, even at a loss, to a man who enabled him to organize operations amounting to hundreds of thousands of liores and yielding profits that, although difficult to estimate, were clearly considerable. Gradis's Canadian ring formed a critical part of his overall operations and relied to a large extent on Bigot's good will. At the time of his appointment as the intendant of Canada in 1748, Bigot entered into a partnership with Gradis, also establishing relationships with Quebecois officials like Péan and Jacques-Michel Bréard, comptroller of the colonial navy, and local merchants such as Guillaume Estèbe. Gradis, certainly acting out of caution after war was declared with England, withdrew from the Company in 1756, although he continued to serve as the official supplier to the colony and conducted business through his private partnership with Bigot and Péan. These two individuals expanded their commercial operations with their other allies in the province during the Seven Year's War, eventually leading to their internment in the Bastille after the colony fell to the British in $1760 .^{32}$

The Perrens account was entirely different. More or less permanently in arrears by tens of thousands of livres-essentially an interest-free loan from Gradis_-, in a single day the account was credited for more than 80,000 £.t. for royal supplies, a considerable sum for the period. This positive balance vanished two weeks later, however, leaving the account once again in the red. This yo-yo-like swing between

32. The "Canada Affair" erupted in the Fall of 1761 with the arrest of Bigot, Péan, and their associates on the order of the new Secretary of State of the Navy, Nicolas René Berryer. In 1763, Bigot was banished for life, and his property was confiscated. He spent his final years in Switzerland, living relatively comfortably thanks to funds he was able to preserve through Gradis's efforts, among others. See Denis Vaugeois, "François Bigot, son exil et sa mort," Revue d'histoire de l'Amérique française 21-4 (1968): 731-78. Due to the possible impact on the ability of the French colony to resist the British enemy, the monopolizing behavior and influence-peddling of Bigot and his merchant allies, including Gradis, have been the ongoing focus of often violent condemnations in Quebec. John-Francis Bosher and Jean-Claude Dubé express the belief, however, that it is difficult to determine whether Bigot "was an especially corrupt intendant or simply a type of intendant that emerged within a corrupt system," a conclusion previously reached by Guy Frégault in François Bigot. Administrateur français (Montréal: Guérin, 1948; repr. 1996). See John-Francis Bosher and Jean-Claude Dubé, "François Bigot," in Dictionnaire biographique du Canada en ligne, http://www.biographi.ca/index-f.html (original ed.: vol. IV, 1771-1800, 1980). 
surplus and deficit corresponded to the fluctuating amount of Gradis's supplies, which was periodically debited to the King, one cargo at a time. Perrens thus functioned as an extension of the Gradis firm and as the cornerstone of the Quebec supply ring on the supplier's side. As for Marchand Fils, the account balance was only settled later, when Gradis was refunded for advances he had made for a new adventure on his partner's account. Once again, the debt only acquired meaning within the framework of a specific trading ring, that of Gradis's trade in outfitting ships. The widow La Roche's debt was subject to a different accounting fate, since Gradis transferred her negative balance to his "Suspended Interests" account, in which he listed questionable or hopeless debts. In the absence of efforts to recover the debt, this transfer demonstrates Gradis's adhesion to a charitable vision of economic relationships, whereby certain debts could be forgiven under particular circumstances. This confirms that he belonged to a social network in which an excessively economic approach to the situation would have appeared unseemly. His gesture was only possible, however, because the widow played a minor role in a supply ring that included Gradis. He would not have been able to be so magnanimous had the widow been a crucial partner in a more significant sector of the market.

Every account outlined the narrative of a particular relationship, of which the meaning unfolded within the specific context of mercantile buying and selling rings involving both borrower and credit-holder. The organization of each ring and the place occupied by each participating account-holder are important parameters in assessing the nature of this relationship. Furthermore, although they cannot be described as truly non-economic, a number of these parameters remain unquantifiable nonetheless. For Bigot, like for the widow La Roche (though somewhat differently), investments that appear to have yielded losses could be simultaneously interpreted as consistent with the social rules of the period (submitting to highranking figures in the kingdom, maintaining a charitable attitude with respect to weaker figures, etc.) and as economic decisions yielding indirect returns, which included having access to the Canadian market (Bigot) or maintaining a good reputation among Aquitaine trading rings (the widow La Roche). Making a sharp distinction between these interpretations does not make a great deal of sense: the social contents of these decisions were an important factor in their economic character, a point which was just as true when it came to investing in royal supplies or firms involved in providing outfitting and shipping services. In both cases, Gradis's choices had a concrete economic impact on the respective rings, if only because of the size and timing of the advances. Naturally, the king was an exceptional debtor who justified an advance of 80,000 liveres for a period of nearly six months. The return on investment was not solely, and perhaps not even mostly, monetary. (Indeed, the royal debt to Gradis was never completely cleared.). His return was also comprised of prestige and potential protection, elements that were obviously important to Gradis's evolving position within multiple rings, a number of which were not connected to supplying the province of Quebec. The situation with the syndicates organized by Marchand Fils was similar, if less significant. 
Advancing 25,000 livres with no immediate return to a merchant operating in the same city was an act of trust and shared enterprise yielding benefits that were not strictly economic but that instead belonged to the broader framework of daily collaboration, both past and future. Friendship could play an economic role without necessarily being insincere.

A correspondent was also a source of credit when it came to advancing funds. The size of an advance depended on both the lender's situation (it was better to have correspondents with a backbone and who would not abruptly demand that their account be settled at an inopportune moment) and the history of credit relationships between two interlocutors who both belonged to a more or less local mercantile ring. Personal reputation played a role in addition to what can be viewed as non-economic ties. Family connections, shared religious or national affiliation, and other factors could contribute to the formation of bonds that might encourage a creditor to be more patient or a debtor more punctual. In this way, each mercantile relationship engendered a line of credit in the current sense of the word, meaning the ability to derive benefits from the relationship through favorable modes of payment or tolerance of deficits in current accounts. It is clear, in any case, that payments were constitutive of a partnership in the same way as transfers of merchandise and that both types of transactions were based, in principle at least, on mutual trust. It is also apparent that profits were distributed according to complex rules of differential participation in risk, rules that were once again partly determined by the history of the relationships between partners within the context of a particular trading ring.

In terms of volume, the current account was one among several crucial sources of credit. The principal source of credit for mercantile accounts was commercial paper-meaning a formalized advance of funds - with a fixed term beyond which interest would accrue according to an established percentage. This type of support was far more abundant than cash payments, due in particular to the comparative rarity of cash in both the American colonies and the large trading cities of western Europe. Commercial paper was far more frequent in these urban settings than direct cash loans, which David Hancock describes as "extraordinary" compared to "ordinary" credit involving delayed payment. ${ }^{33}$ Commercial paper had been used as a method for transferring funds from place to place since the Middle Ages. ${ }^{34} \mathrm{It}$ had since become widespread and lost any connection to capital transfers. In any kind of transaction, if there was an agreement between creditor and debtor, the debtor could issue commercial paper for a given amount of capital through an English "note of hand" or a French billet à ordre (promissory note). The lender usually entered it in a Lettres et billets à recevoir or "Bills Receivable" (meaning

33. Hancock, Gitizens of the World, 247.

34. Raymond De Roover, L'évolution de la lettre de change, XIVe-XVIIIe siècle (Paris: Armand Colin, 1953); James Steven Rogers, The Early History of the Law of Bills and Notes: A Study of the Origins of Anglo-American Commercial Law (Cambridge: Cambridge University Press, 1995). 
owed by others) account. The paper instrument could also be used to settle thirdparty debts. The endorsement and free circulation of commercial paper allowed these instruments to function essentially like currency, albeit a currency of which the liquidity was contingent on acceptance by the sequence of parties who held the paper.

Commercial paper differed from current accounts in that it formalized the timeframe and attached potential interest to a credit, even if the degree of formality varied widely. Everything involving the date and mode of payment of the debt depended on the context and relationship between signatories. Among many operators, payment dates-including the initial interest-free period-as well as the transfer (discounting) and renewal fees were variable, and the exchange rates actually practiced were the legal rate or could involve either a concealed usurious rate or a rate below the official rate. In any case, a creditor rarely required that a debt be settled in full by the date of maturity of the paper, and the debt was usually refinanced with a higher balance incorporating the interest that had accrued. Even when payments were made, they varied. Among other choices, a creditor could require cash or accept commercial paper, which could be more or less secure and exotic, or choose to impose a discounted rate on paper. The negotiation was never one-way, since the party entering into a debt could always refuse to honor it if he or she judged the creditor too greedy. When that occurred, the creditor could face high transaction costs, since litigation was long and costly, with no assurance of recovering his or her investment; borrowers involved in such cases risked becoming insolvent because of damage to their reputation caused by litigation. The risk of insolvency alone served to dissuade debtors from defaulting, but the risk could become more acceptable if a debtor was able to portray the incident as isolated. ${ }^{35}$ In any case, commercial paper could be more or less liquid depending on the size of the group within which a debtor was sufficiently well-known for the paper that he or she issued to be transferred with little difficulty and with few discounting fees. Liquidity was also an important element with regard to the attitude one adopted when refinancing debt. Commercial paper ultimately functioned both like merchandise and a current account. Like a current account, commercial paper was an outgrowth of an initial personal relationship that was transformed into a chain of personal relationships and rendered more liquid; like merchandise, acceptance implied a series of complex choices on the part of each party involved concerning the qualities that would be ascribed to the debt.

Both kinds of credit combined-commercial paper and current account credit-interacted at every level of mercantile activity, from supplies to the circulation of commercial credit and capital advances, meaning that each actor functioned much like a bank. Comparing the roles of commercial paper and current accounts in this context is complex. In part, this is because some series of transactions that 
relied on commercial paper were recorded based on the initiating and final debtors, with no clear indication that a transfer of paper was involved, as in the following entry: "Fereire de la Gouadeloupe Dr to Luker $£ 150$ p For his bill of 2 June last on sight payable to Gilbert de Venion fils which said Luker remitted to us." 36 This apparent compensation of one account by another corresponds to two sequential payments using commercial paper: Luker paid Gradis with a promissory note from Fereire drawn on Gilbert de Venion fils, which Gradis canceled by carrying the balance over to Fereire's debt, the equivalent of converting a paper credit into a current account credit. However, the ledger only reflects the transfer of value between Luker and Fereire's accounts. In this case, the only solution is to verify each entry, which, for the year 1755 , revealed that 280,000 £.t. in paper were transferred from one account to another without being recorded as such, which corresponds to a sum of 560,000 £.t. to add to the total value of paper payments for the year.

A further problem in analyzing the bookkeeping records of the period is that a certain number of transactions seemingly based on credit were, in reality, cash transactions that were delayed for several days. For example, Gradis sold merchandise to a partner who transferred the corresponding funds to Gradis several days later, quickly enough that the two transactions should in fact be considered as one transaction. I assessed the average rhythm of transactions on personal accounts with Gradis and entries recorded seven days or less after the preceding entry on the same account represent nearly $40 \%$ of all recorded delays between entries, ${ }^{37}$ while those transfers that occurred between eight and fourteen days apart represent only $18 \%$ and those recorded during the third week represented $11 \%$. It is thus possible to estimate that any payment made less than seven days after the initial transaction could be considered a "cash" payment, which is the limit that I have chosen to apply.

Once transfers of commercial paper and cash payments hidden in the accounts are accounted for (a process subject to error, which has led me to use round figures), figure 4 confirms the importance of credit in the operations of the period. The prominence of free and informal credit-meaning compensations from one account to another that did not involve cash or commercial paper either immediately or in the days that followed-is far from negligible. Nearly one-fifth of the value of transactions was generated with no recourse to cash or commercial paper and solely through transfers of funds from one current account to another current account. In all, nearly $70 \%$ of payments involved credit. Ultimately, nearly twothirds of the total movements of funds were due to the purchase or sale of commercial paper, with only $12 \%$ of purchases or sales settled on the spot for their face value in cash.

36. Journal 1751-1755, 22 January 1755, Fonds Gradis, AN, Paris.

37. This is true of 753 entries observed at least one day apart and at most ninety-nine days after the previous entry in the same personal account. Entries separated by a more than a one hundred-day delay are relatively rare: only seventy-one were noted. 


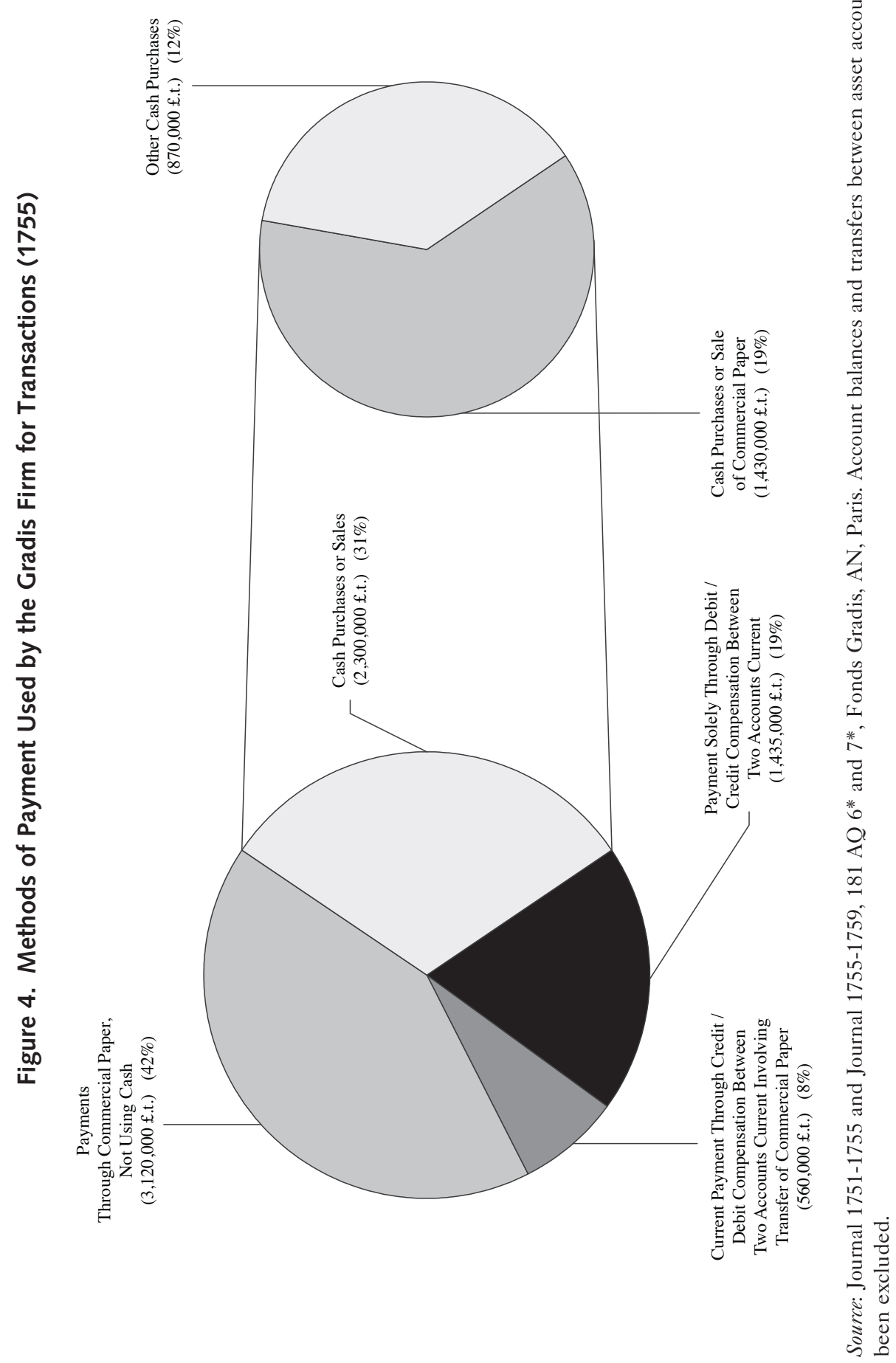


Clearly, credit played a major role in the movement of funds, and there is little doubt, although it is impossible to be certain, that its share of assets and liabilities was equally important. Gradis rarely balanced his books, and the only accounts that were regularly settled were the commercial paper accounts, Lettres et billets à payer (Bills Payable) and Lettres et billets à recevoir (Bills Receivable). For the year 1755 , Gradis issued approximately 430,000 £.t. in refundable commercial paper, and the portfolio of debts owed to him by other actors varied between 500,000 and 965,000 £.t., depending on the season (commercial paper was often received in late fall, in payment for the previous year's transoceanic shipments, and was discounted out in late winter, when the previous year's suppliers were paid). It is also possible to compute the apparent annual balance of movements in the principal accounts-which does not correspond to the true balance because the starting balance of each account is unknown. The Caisse (Cash) account, for example, could not issue more than it received, which implies that Gradis began the year with several tens of thousands of £.t. in his till.

Table 1 - Movement of Funds in Gradis Firm Accounts (1755)

\begin{tabular}{|c|c|c|c|}
\hline Debit (Dt.) & $\begin{array}{c}\text { Annual Balance } \\
\text { (Inverted Sign*) } \\
\text { \&.t. }\end{array}$ & $\begin{array}{c}\text { Paid To (Dt.) } \\
\text { \&.t. }\end{array}$ & $\begin{array}{c}\text { Paid By (Cr.) } \\
\text { £.t. }\end{array}$ \\
\hline Cash & $-32,000$ & $-1,100,000$ & $1,132,000$ \\
\hline Bills Receivable & 139,000 & $-1,275,000$ & $1,136,000$ \\
\hline $\begin{array}{l}\text { Other Accounts (Personal, Real, } \\
\text { Armements, Insurance Premiums, Etc.) }\end{array}$ & $-80,000$ & $-1,879,000$ & $1,959,000$ \\
\hline Debit Balance & 27,000 & & \\
\hline Credit Cr. & $\begin{array}{l}\text { Annual Balance } \\
\text { (Normal Sign) }\end{array}$ & Paid To (Dt.) & Paid By (Cr.) \\
\hline Bills Payable & $-4,000$ & $-500,000$ & 496,000 \\
\hline Profits and Losses & 31,000 & $-92,000$ & 123,000 \\
\hline Credit Balance & 27,000 & & \\
\hline
\end{tabular}

Source: Journal 1751-1755 and Journal 1755-1759, $181 \mathrm{AQ} \mathrm{6*}$ and 7*, Fonds Gradis, AN, Paris.

* N. B.: for readers familiar with accounting practices, I have inverted the sign of debit accounts in order for growth or decreases in value to be more easily discerned by nonspecialists. In terms of credit, a positive balance in the "Profits and Losses" account is the equivalent of the same amount of capital growth, either used to increase the value of assets on the debit side or in order to reduce that of the liabilities, both of which are the case here.

The amount of capital held by the Gradis firm on the death of its founder David Gradis in 1751 is known with a certain degree of precision and was estimated at approximately 450,000 £.t. This was probably multiplied by a factor of ten between 1751 and 1780, reflecting an average annual growth rate of $7 \%$, although the threeyear period between 1752-1754 must have been comparatively prosperous years 
considering the difficulties encountered by the Gradis firm a few years later, when they attempted to be reimbursed for their advances to the King for provisioning Quebec. ${ }^{38}$ By adopting a cautious estimate of $10 \%$ annual growth rather than $7 \%$ for these early years in order to avoid underestimating capital and thereby overestimating profit, Gradis's net worth in early 1755 would have been approximately 600,000 \&.t., despite the fact that the actual total value of the transactions conducted during that year surpassed 8 million £.t. By this measure, the roughly 31,000 £.t. earned in the year-of which approximately 4,000 £.t. were devoted to reducing liabilities and 27,000 £.t. were reinvested into debit accounts-represent a net profit of slightly over $5 \%$. This profit margin is higher than might be expected, ${ }^{39}$ and it corresponds relatively well to the firm's growth rate between 1750 and 1780 . However, these calculations are approximate, and it is important to consider eventual modifications of the available stocks of merchandise and of the structure of investments, credits, and debts-not to mention the depreciation of assets, which was almost never taken into consideration at the time.

The overall volume of activity, at slightly over 4 million £.t. in income and receivables in the course of the year (of which scarcely one-fourth was in cash) based on an estimated capital of approximately 600,000 £.t., tends to confirm the overwhelming prominence of credit in economic practices of the time. Again, it should be noted that Gradis was an important trader in a European market in which cash transactions were not unusual, even if they were less frequent than in London or Amsterdam. For a trader such as Hollingsworth, who traded at the margins of these core markets, the significance of credit may have been even greater. ${ }^{40}$ The existence of an account labeled Caisse (Cash) should not be misinterpreted, since commercial paper and other diverse forms of paper instruments were also deposited in it. This is demonstrated by the fact that Hollingsworth only rarely deposited commercial paper in his "Bills Receivable" account (sixteen such notes were recorded as deposited in a ten-month period from March to December, 1786), and only amounts of over 100 £.P. (Pennsylvania pounds) were recorded, despite the fact that he kept track of the paper notes that he issued through a "Bills Payable" account (165 paper notes were issued during the same period, approximately one every two days). Instead of being limited to calculations based on transactions that passed through the "Cash" account, it is easier to evaluate precisely the role of credit in Hollingsworth's case using the detailed balance sheet

38. Menkis, "The Gradis Family," 111 and 124.

39. Such a return rate is comparable to the rates found in long-distance trade, including the slave trade: see Guillaume Daudin, "Profitability of Slave and Long-Distance Trading in Context: The Case of Eighteenth-Century France," The Journal of Economic History 64-1 (2004): 144-71, especially table 4, p. 167.

40. On the absence of cash transactions in the United States, see: William T. Baxter, The House of Hancock: Business in Boston, 1724-1775 (Cambridge: Harvard University Press, 1945); Farley Grubb, "The Circulating Medium of Exchange in Colonial Pennsylvania, 1729-1775: New Estimates of Monetary Composition, Performance, and Economic Growth," Explorations in Economic History 41-4 (2004): 329-60. 
he created nearly every two years. Table 2 presents this balance sheet for the year 1788, which covered the previous two-year period of 1786-1788.

Table 2 - Balance Sheet of Levi Hollingsworth (1788)

\begin{tabular}{|c|c|c|c|}
\hline \multicolumn{2}{|l|}{ Assets } & \multicolumn{2}{|l|}{ Liabilities } \\
\hline Real Estate & 19,034 £.P. & Creditors (298) & 20,685 £.P. \\
\hline 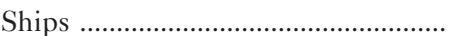 & 850 £.P. & "Suspended" .... & 3,264 £.P. \\
\hline Merchandise ....................................... & 1,638 £.P. & Original Capital ........................................ & 25,654 £.P. \\
\hline Adventures ………………… & 2,213 \&.P. & Profits/Losses Account (Balance). & 922 £.P. \\
\hline Debtors $(388+$ ????) .......................... & 25,849 £.P. & & \\
\hline Paper Money ……………………........... & 128 £.P. & & \\
\hline 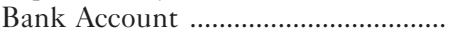 & 112 \&.P. & & \\
\hline 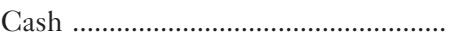 & 701 £.P. & & \\
\hline 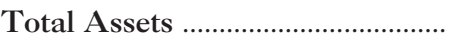 & 50,525 £.P. & 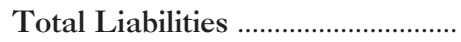 & 50,525 £.P. \\
\hline
\end{tabular}

Source: "Journal L (February 20, 1786-January 31, 1788)," 86 and "Ledger L (February 20, 1786-February 1, 1788)," 21, Hollingsworth Collection, Historical Society of Pennsylvania, Philadelphia, in Pennsylvania pounds (£.P.).

Credits constituted half of his assets, while debts represented almost half of his liabilities. Furthermore, the status of his real estate holdings is unclear. Hollingsworth owned land in western Pennsylvania and Virginia that was neither occupied nor controlled by the federal government and of which the value was therefore purely speculative. As was the case for Gradis, operations recorded in "Profits and Losses" were far inferior in value to credit-based operations: for the year 1787-1788, his "Profits and Losses" account reflects 2,739 £.P. credit but 1,817 £.P. debit, a net credit balance of (and hence profit) of 922 £.P., a paltry increase of less than $3.5 \%$ per year. However, Hollingsworth also constantly drew money on his own account for his daily expenditures, which suggests that this figure is hardly representative.

The prominence of credit in terms of both assets and liabilities had one final and very important consequence for every merchant: each figure that appeared in their balance sheets, in their settlements of accounts or even when calculating stock was completely theoretical. The majority of the stock and account balances were comprised of commercial paper and credit on current accounts of which, to an even greater extent than in today's bookkeeping practices, the real value could be significantly inferior to the book value because they had no institutional basis, and there was little recourse available to creditors in the event of non-payment. ${ }^{41}$ Movements of funds in the personal account that Gradis opened for Bigot during 1755 were on balance negative of 250,000 £.t. It is highly probable that this sum did not correspond to any pre-existing credit arrangement and that Gradis would have experienced difficulty if he had sought to be reimbursed for what amounted to a concealed form of remuneration for favors granted to the Gradis firm by one of the most powerful officials in colonial France. This "asset" was therefore profitable, 
doubtless even extremely so, but its book value was close to zero. Indeed, the existence of this negative but highly profitable balance suggests that, in order to assess Gradis's profits on his trade with Quebec, this sum should be deducted and considered a hidden cost.

From a more general perspective, any commercial paper could be contested, and a current account overdraft could become unrecoverable in the event of bankruptcy. In fact, even other assets possessed only relative value: real-estate values could drop precipitously (especially in the colonies), and merchandise shipped to Cork or the Caribbean could later be found spoiled or had to be sold at a loss. The Gradis and Hollingsworth account books were thus to some extent a mental exercise, a mirage that was only sustainable if separated from the real world, unlike today's accounting practices and records, which make every effort (albeit with variable success) to keep posted values up to date. Real merchandise, real cash, and real commercial paper also existed in the eighteenth century, but the art of maintaining a balance between what should be liquidated and what was best deferred for later examination constituted the true core competence of these traders' work. This also largely explains why, when detailed balance sheets were created, they served, at best, as an indication of the overall financial condition. Above all, the final balance sheet was only partly reflected by accounting practice. The apparent return on investment was less important than the evolution of abstract, non-liquid assets, which must have been the major preoccupation of the rational merchant of the day: one's reputation, a corresponding ability to join specialized trading rings that more or less dominated particular market segments, and the access that for some actors flowed from this domination if they were able to supply the information or credit necessary for certain operations. The entire credit pyramid was founded on these types of assets, which, to a far greater extent than what was often limited available capital stock, constituted the real source of profit.

\section{Accounting Practices and Credit}

Economic activity of the early modern period centered on widespread, continuous credit of which the value was broadly fiduciary and which was the dominant mode of economic exchange within specialized mercantile rings. These rings were created with the intention of controlling, if not all, at least part of generally narrow market segments that developed based on complex path dependencies and in which numerous institutions and individuals, beginning with the government, were repeatedly involved. This observation concerning the markets of the period makes it possible to reinterpret the "capitalist" spirit of accumulation and, in particular, the accounting practices of the period. For many authors, double-entry bookkeeping symbolizes the transition from a medieval economy toward a modern capitalist economy, a perspective embraced by Max Weber and Werner Sombart. ${ }^{42}$ 
The practice first appeared in the fifteenth century and, by the eighteenth century, was fairly widespread among large-scale traders (although it was infrequently used by individuals operating on a smaller scale). It apparently represented a precious research tool for measuring performance and profit, two supposedly fundamental components of the "capitalist" mentality. Based on a series of seventeenth- and eighteenth-century accounting manuals, John Edwards, Graeme Dean, and Frank Clark have recently argued that the people at that time did in fact quantify their estate-which included their goods and property, as well as the increase and decrease in their wealth, profit on specific operations and merchandise and the costs associated with them, merchandise inventories and their value, and, in a general way, their firms' performance-, enabling them to make informed decisions. ${ }^{43}$ Robert Bryer contends that double-entry bookkeeping provided users with a clear estimate of return on invested capital, even if, as Edwards has also noted, there are few known examples of such retrospective profitability calculations prior to the nineteenth century, a dearth of examples that tends to weaken this argument. ${ }^{44}$

As other scholars-notably Basil Yamey-have observed, accounting practices of the early modern period do not appear to have focused on these kinds of calculations. ${ }^{45}$ The archetype of the merchant with a Marxian "capitalist" mentality (or "calculating" in Weberian terms), who used accounting practices to help guarantee a maximum return on investment and maximization, essentially did not exist in the eighteenth century. The vast majority did not use double-entry bookkeeping, instead recording transactions in the order in which they occurred or, at best, in current account ledgers. Even those who resorted to a complex two-part system rarely balanced their accounts and almost never used their books to calculate returns on particular products. Partnerships could function for years without distributing profits, and only investments that were "socialized" through a share system produced regular payments. Calculations of the profitability of investments were extremely rare. Steven Toms has identified only fourteen known cases between 1611 and 1800 . Toms has also noted that laws governing usury imposed a ceiling on profits that could be generated by credit; these laws thus directly contradicted the objective of achieving a return on investment that Bryer and, more implicitly,

Max Weber, General Economic History, trans. Frank H. Knight (New York: Greenberg, 1927). Current perspectives on this issue are summarized in John R. Edwards, Graeme Dean, and Franck Clarke, "Merchants' Accounts, Performance Assessment and Decision Making in Mercantilist Britain," Accounting, Organizations and Society 34-5 (2009): 551-70. See also Hans Derks, "Religion, Capitalism and the Rise of Double-Entry Bookkeeping," Accounting, Business and Financial History 18-2 (2008): 187-213.

43. Edwards, Dean, and Clarke, "Merchants' Accounts."

44. Robert A. Bryer, "The History of Accounting and the Transition to Capitalism in England. Part One: Theory," Accounting, Organizations and Society 25-2 (2000): 131-62; Bryer, "The History of Accounting and the Transition to Capitalism in England. Part Two: Evidence," Accounting, Organizations and Society 25-4/5 (2000): 327-81.

45. Basil S. Yamey, "The 'Particular Gain or Loss Upon Each Article We Deal In': An Aspect of Mercantile Accounting, 1300-1800," Accounting, Business and Financial History 10-1 (2000): 1-12; Jeannin, Marchands du Nord, 82; and Richard Grassby, "The Rate of Profit in Seventeenth-Century England," The English Historical Review 84-333 (1969): 721-51. 
Edwards say drove accounting practices at the time. Toms also points out that useful tools for measuring profit on inventory or in a multi-division context were not developed before the nineteenth century. ${ }^{46}$

In fact, double-entry bookkeeping should be considered within the context of the organization of early modern mercantile activity focusing on the question of credit. Period accounting manuals, particularly those that reached a broad audience and even became classics, provide rich resources for understanding this question. It seems reasonable to suppose that these textbooks, which were written to instruct apprentice merchants, presented a perspective on accounting practices that was not far removed from the views of their intended audience. While acknowledging the danger of confusing theory and actual behavior, it is still possible to view these manuals as expressing an approximation of their readers' perspectives on the usefulness of accounting tools. Mathieu de La Porte, by far the most widely published eighteenth-century author of French-language accounting manuals, ${ }^{47}$ asserted this in the preface to one of his texts.

It must nevertheless be agreed that a merchant who uses cash for all his purchases, who borrows neither merchandise nor money for his Commerce, \& who lends nothing to anyone, could dispense with maintaining \& keeping books, because he cannot fall into any of the cases described by the Ordonnance. He has neither active nor passive debts; as a consequence he fears neither failures nor bankruptcies, \& he is in no danger of failing himself, nor of causing losses to his Creditors, because he has none. This case is not without example, and I have seen a Merchant (a retailer, in truth) who, during the more than sixty years that his shop was open, although he even had a fair amount of business, never borrowed nor loaned anything, \& as a consequence he had no Book: However he conducted his business with much honor and probity, \& without encountering any financial difficulties. But this is a very rare thing, \& could not be the case of a Merchant with a somewhat considerable trade. It is therefore necessary for he who borrows and lends to keep his books very exactly, in order to see at all times the state of his Affairs. His Books will teach him which affairs and which negotiations have profited him or caused him losses, and he will know who are his debtors and creditors, in order to satisfy the latter and get himself paid by the former, \& furthermore he will be in a condition to be able to account for his conduct, in the unfortunate event that his affairs began to suffer and he not have what he needs to satisfy his Creditors. ${ }^{48}$

46. J. Steven Toms, "Calculating Profit: A Historical Perspective on the Development of Capitalism," Accounting, Organizations and Society 35-2 (2010): 205-21. See also Alfred D. Chandler, The Visible Hand: The Managerial Revolution in American Business (Cambridge: Belknap Press, 1977).

47. According to Pierre Jeannin, the only significant French author who was comparable in the eighteenth century was Jacques Savary: see Jeannin, Marchands d'Europe, 382. See also Yannick Lemarchand, "Jacques Savary et Mathieu de La Porte: deux classiques du Grand siècle," in Les grands auteurs en comptabilité, ed. Bernard Colasse (Colombelles: Éd. EMS, 2005), 39-54. 
According to de La Porte, accounting existed only because of its connection to credit. Furthermore, while credit exposed merchants to the risks of personal failure and being cheated, no "somewhat considerable" commerce could exist without it. In the absence of credit, there was no significant exchange, risk, or obligation. Therefore, there was no need to maintain accounts. Except for the rare case of aurea mediocritas described by de La Porte, it is safe to argue that, in his view, the notion of credit encompassed every facet of mercantile activity.

An overly hasty reading of this passage could lead to the conclusion that, in emphasizing the importance of knowing "which negotiations have been profitable, and which have led to losses" and the "state of one's affairs," de La Porte was channeling a calculating "capitalist" mentality. In reality, though, the meaning of profits and losses, like one's financial condition, should be understood within the framework of the credit relationship. Cash transactions were explicitly rejected outside of the sphere of operations one had to control and were presented as utterly transparent and risk-free. Calculating profits and losses was therefore pointless in such cases because, once the inherent difficulties of evaluating products were resolved, the outcome of the transaction was immediately clear. In fact, de la Porte did not address questions of overhead costs, supply and demand, and pricing, since any merchant who sold for cash could also spare himself the trouble of recording such matters. This implies that only credit engendered uncertainties concerning profit. Such uncertainties, moreover, were not necessarily quantifiable because, in the event of bankruptcy, the final balance sheet would ultimately be based on a merchant's "conduct," meaning on his or her proper use of credit and not merely on the figures in his or her numerical statement.

The importance of credit is not a particularity of Francophone manuals, nor is the need to carefully analyze the meaning of terms used to avoid the risk of anachronistic interpretation. The British author John Mair's Book-Keeping Methodiz'd was the most reprinted Anglophone accounting manual in the eighteenth century. In his introduction, Mair explained the following:

A Merchant who deals in proper Trade ... ought to know, by inspecting his Books, to whom he owes, and who owes him; what Goods he has purchased; what he has disposed of, with the Gain or Loss upon the Sale, and what he has yet on hand; what Goods or Money he has in the Hands of Factors; what ready Money he has by him; what his Stock was at first; what Alterations and Changes it has suffered since, and what it now amounts to. ${ }^{49}$

At first glance, this excerpt appears to justify the position of scholars who see indications of the rise of the "capitalist" mind-set in eighteenth-century accounting

que pour les Marchandises, \& chez les Financiers pour les Comptes (Rouen: P. Machuel et J. Racine, 1704; repr. 1782), VIII-IX.

49. John Mair, Book-Keeping Methodiz'd: Or, a Methodical Treatise of Merchant-Accompts, According to the Italian Form, $3^{\text {rd }}$ ed. (Edinburgh: W. Sands, A. Murray, and J. Cochran, 1749), 2. This book was first published in 1736 . 
practices. While credit ranks high among the objectives of accounting during this period, tracking inventory and determining profits and losses in addition to the flow of capital reflect a vision of accounting that is both far more global and more precise, with analysis of loss and profit on each transaction type framed from the outset as a key outcome of the accounting process.

Appearances, however, are deceiving. In both the balance sheet and the description of accounts, the question of profit remains peripheral for reasons that are not immediately obvious. Unlike de La Porte, Mair does not address the main principles of his approach in his preface. Instead, it is only by examining the account structure itself that these principles become apparent. Mair discusses this structure immediately after the opening paragraph quoted above.

[An accounts ledger should] contain a record of all the Merchant's Transactions and Dealings in a way of Trade; and that not only of such as are properly and purely mercantile, but of every occurrence that affects his Stock, so as to impair or increase it; such as, private Expences, Servants Fees, House-rents, Money gained or lost on Wagers, Legacies, and the like... The Ends proposed in Book-keeping can never be gained, if such Things as these pass unrecorded. For since one of the Designs of Book-keeping is, to put the Merchant in case at any Time to compute, by the help of his books, what he is worth to a farthing, it is plain that this he can never do, if Things are left out by which his Stock is actually lessened or enlarged. ${ }^{50}$

Measuring the profits from mercantile activity as a separate category, distinct from an entire series of activities, was therefore out of the question. Mair concludes: "By such Occurences as these, a Merchant as effectually becomes so much poorer or richer, as by the Result of any Branch of his Trade"! ${ }^{1}$

In and of itself, attention to a fair evaluation of personal holdings in their broadest sense, mixing personal and commercial activities, could easily leave room for periodic calculation of losses and profits that distinguishes between the two. A merchant could create an account labeled "Sugars" that included a list of expenses associated with purchases and sales of sugar and calculate the net profit on that product when the account was balanced. This is what Mair called "Loss or Profit on sale." But a careful reading of the accounts he suggests shows that he was not reasoning directly in terms of account activity and that his thinking was structured by an important intermediate phase. In his view, accounts "are of three kinds, vi\%. personal, real, and fictitious. A personal Dr. or Cr. is a Person's Name; as David Wilson in the preceeding [sic] Post. A real Dr. or Cr. is a Thing; as Cash, Sugar, Shalloon, \&c. A fictitious Dr. or Cr. is a Term made use of to supply the want or personal or real one; as Profit and Loss, Voyage, \&c." 52 A choice had to be made whether or not to create a separate account based on these three broad categories. 
While the first two categories- "personal" accounts (those of individuals to whom a merchant lends or from whom he borrows) and "real" accounts-are not difficult to understand, the notion of a "fictitious" account merits further exploration. The primary fictitious account is "Profits and Losses." Mair explains that cases that "cannot properly be divided into a Dr. Part and Cr. part, but consist of one of these parts only" should be recorded under this account. An initial set of examples includes not only an inheritance received by a friend or any other gift of merchandise or money, but also "Shop-rent, Warehouse-rent, or other Things of the like nature." ${ }^{53}$ What matters is the assumed common nature of the operation, not its origin nor its significance in terms of loss or profit. Mair is explicit with regard to this point: "It were indeed to be wished, that we had some English Word of such a general Signification, as to be equally applicable to denote Gain or Loss." 54 But how can a profit or loss be of the same nature? And what is the common denominator between an inheritance and renting a storage warehouse?

In fact, the connection between these operations relates to the actors involved. A gift of merchandise, money won when gambling, and a ship that disappears at sea are definitive outcomes that increase or decrease holdings without creating a transactional relationship with a third party. In short, it is the trader who credits or debits himself or herself for the loss or profit and who directly contributes to or takes from a particular account. If a merchandise account receives a certain quantity (and value) as a free gift, the gift in a sense comes from the trader alone, since no one else will be credited for it. The operation functions as a simple capital increase. Similarly, the value possessed by a trader that goes down with a ship is not owed to another party: it is as though the trader destroyed it by deleting it from his or her capital, after duly removing or reducing the balance of the relevant account. The same reasoning applies to the warehouse rentals and other "fees" to which Mair refers: the only identifiable beneficiary of such expenses is the trader, who decides to reduce his or her capital for a corresponding amount. Since such an operation generates no new stock and does not increase available credit, it is considered an unproductive expense, a net loss from the point of view of accounting for the period, and an illustration of the extent to which the latter was unaware of the notion of costs as perceived today.

Like de La Porte, Mair bases his accounting on the relationship between debtor and creditor, explaining the dichotomy between, on the one hand, what he termed a "complete" transaction taking place between two personal or real accounts and, on the other hand, all transactions involving the "Profits and Losses" account, which take place between the trader and one of these same accounts. From this perspective, there is no duality between personal and real accounts, meaning between credits obtained from or granted to other actors and assets-merchandise or paper. As Mair explains, both account types had the same status as a source or recipient for credits that circulate endlessly among different accounts. The insistence on an instant photographic duplicate yielded by the two columns of debit

53. Ibid., 17.

54. Ibid., 19. 
and credit-the "exact and correct vision" so ardently sought by the royal orders in France and private acts in Great Britain ${ }^{55}$ - primarily concerns measuring the exact distribution of a trader's possessions between different objects and debtors to whom this value was more or less initially "given in trust." The problem is that following the initial distribution, a maze of transactions caused parts of the original deposit to shift from one account to another. Double-entry accounting enabled this circulation to be tracked, minimizing the risk of error so as to be able to retrace what Mair and other authors of the period mostly viewed as a series of loans to individual accounts-, in other words, as a sequence of credit acts.

In stark contrast to this fundamental mechanism of the circulation of capital or credit flow, the "Profits and Losses" account revolved around transactions between the trader and his properties, either as funds that were spent and considered lost or through the addition of external funds, without the involvement of a third party. This does not mean that accounts remained unchanged (a cash inheritance increased the value of the "Cash" account, just as a gift of fabric increased the balance of the merchandise account or a purchase on credit increased "Bills payable," etc.), but these modifications were the autonomous acts of the proprietor and were subject to his or her sole responsibility, a sovereign act at the modest level of the proprietor's own accounts, which arose from the same principle as the initial "gift" through which capital was distributed to the different accounts. According to both Mair and de La Porte, the accounting structure of the period relied heavily on analysis of one's relationship with the credit act expressed by a transaction, which entailed either a transfer of credit from one account to another or a sovereign gift or withdrawal by the owner.

This is confirmed by the description given by Mair of the only other "fictional" accounts that he mentions, the so-called "adventure accounts." He explained that, "when a Merchant sends Goods to Sea, ... there is no Dr.; for neither is any thing received in their stead, nor is the Factor to whom they are consigned, as yet chargeable." 56 Creating an adventure account therefore represented another autonomous act by the trader, who divided his or her stock by creating a sub-entity because no third party was involved in the transaction. This analysis is all the more remarkable in that, according to any logical process, an adventure account should be conceived of as a real assets account in the same way as "Sugars" or "Wines" accounts, since it too contains merchandise given by the proprietor. But Mair preferred to emphasize the change in status of the merchandise, which is no longer stocked under the merchant's direct control but is also not under the control of the purchaser. The physical dispossession of the merchandise-which enters into a kind of limbo beyond its proprietor's reach-justified placing it into a new account, which remained "fictional" since there was no third party who could be debited or credited for the transaction.

55. The Order for France was declared in 1673. For England, see R. J. Chambers and P. W. Wolnizer, "A True and Fair View of Position and Results: The Historical Background," Accounting, Business and Financial History 1-2 (1991): 197-214. 56. Mair, Book-Keeping Methodiz'd, 17 and 36ff. 
For both Mair and de La Porte, accounting was a tool that existed to serve credit, not a method for analyzing the mechanisms of profit. This leads to the question of how this worked in practice. The list of accounts created by Gradis reveals the extent to which accounting manuals reflected the reality of the period. Gradis's accounting is dominated by accounts that record credit relationships, with 211 personal accounts opened for individuals and partnerships. A further two accounts recorded a group of credits granted to diverse individuals who were grouped together because they were similar, including "Freight Receivable from Various Sources," for recording advances by Gradis as payment for fees owed by his principals, and "Freight Payable for the Account of His Majesty." Lastly, eight other accounts reflect credit relationships that were neither personal nor listed in current accounts but which were recorded as more or less contractual obligations: notarial sales contracts, two accounts containing bottomry loans, one of which was with J. Masson of Cadiz, and, of course, every piece of commercial paper, recorded in the two customary accounts, Lettres et billets à recevoir (Bills Receivable) and Lettres et billets à payer (Bills Payable) as well as in two other accounts recording dubious credits: Lettres à négocier (Notes to Negotiate) and Lettres retournées à Protest (Notes Returned in Protest).

The credit relationship also dominated accounts that either recorded assets controlled by Gradis and other individuals or evaded his control entirely. This includes partnership accounts, which encompassed at least three of the fifteen adventure, freight, and armament accounts (and probably a majority of twelve others, though Gradis is unclear whether he owns these himself or whether they were owned by a partnership of which he was a member). Six factorage accounts involved commissions on specific categories of merchandise. These included three wine accounts with various correspondents (for example, "Wines Commissioned to Jonathan Morgan"), a merchandise account, and two commercial paper accounts opened with Mendès Frères, factors in Saint-Domingue, and the two further accounts covering products for which Gradis was himself factor ("Indigos in Commission for Various Parties" and "Sugars and Coffees on Acct of Various Parties"). In reality, all of these accounts involved limited forms of partnership. Although one partner, the broker, did not incur a risk, his or her profit was just as dependent on the outcome of the operation as the the principal's profit because the commission was based on the final results. The broker invested his time and effort, the principal invested his merchandise (i.e., his capital), and the profit was shared differentially, with the principal typically receiving 98\%. Lastly, the three accounts labeled as adventure accounts (for example, "Cargo on Account With the Ship La Renommée") in addition to the twelve adventure accounts belonging to Gradis, of which the status is unclear, present examples of what Mair called "fictional" accounts. These accounts can also be seen as resembling commissions and partnership accounts. Here again, assets were placed in the hands of third parties, captains, or supercargo, and the outcome was essentially suspended for the length of time needed for the entire series of transactions linked to the shipment to be completed and their value conveyed back to the original shipper.

Thus, a total of 232 accounts involved credit relationships, and there were an additional fifteen adventure accounts of more or less indeterminate character, 
compared to only fourteen "real” accounts (in Mair's sense): ten merchandise accounts, the Cash account, two accounts with bankers, and the "Property in Talance" account, in which expenses at Gradis's vineyards were recorded. ${ }^{57}$ Only a tiny minority of Gradis's accounts fall into the category of asset accounts clearly in his own name. Above all, a single account labeled "Profits and Losses," fully consistent with the accounting manuals of the period, indiscriminately recorded every transaction not tied to a credit or a change in stocks of merchandise, with the result that it was impossible to calculate the profitability of real accounts. Indeed, some of the fees on merchandise did not appear to be connected to the activities that generated them; moreover, as time went by, the products or fees that flowed from these activities were lumped together among the entries in the "Profits and Losses" account with no apparent idea of regrouping and analyzing them by assigning them to individual or specific accounts. The only other account that could be considered a record of operational expenses, the insurance premiums account, also had an uncertain status, since the premiums were transformed into assets in case of loss, with the insurer becoming a debtor. If this ambiguity did not exist, it is probable that Gradis would not have considered establishing a separate account. In any event, analysis of his accounting clearly reveals that, like Mair and de La Porte, Gradis primarily sought to measure and control his credit flow, and this preoccupation fully explains the structure of his accounts.

\section{Conclusion: Credit in the Age of Commerce}

Relying on the convenient and plausible archetype of the ahistorical, rational economic agent-or its "capitalist" variant, who calculates his or her return on investment and seeks to maximize it-is not an inevitability. The particular mechanisms of credit in the early modern period, organized around the central notion of trading rings, makes it possible to perceive another rationality that presided over the construction of transactions at the time. It also enriches one's understanding of the practices of mercantile actors without calling into question the pursuit within reasonable limits of the maximized profits or invoking some archaic blindness that led them to only be interested in gross margins or abandon their economic interests. Profit was estimated within the specific framework of mercantile credit, a framework that was necessarily collective and only partly quantifiable. The result was less about mercantile profit, strictly speaking, than about the profit of merchant "rings." In any event, this was not profit as it is conceived today, nor is the credit on which it was founded the same as today's credit. While the vocabulary remains the same, the content has changed, which is what renders contemporary

57. In reality, there were only seven merchandise accounts (General Merchandise; Spirits; Flours; Indigos, our acct.; Purchased Wines; Wines from Talance), since the three acounts "Campeche Wood, our acct.," "Sugars" and "Raw Sugars, our acct." were inactive in 1755. Gradis's two bankers were Chabbert \& Banquet and Gaulard de Journy. 
understanding of many of the terms used in the early modern period particularly problematic.

Eighteenth-century merchants dominated the economy of the period because of this specific strategy, of which the rationality depended on how the tools of production and trade of their society were distributed. For all of them, this strategy entailed acquiring credit, defined as privileged access to capital and information useable in a specific segment of the market and pertaining either to a single product or a specific range of products within a defined space. The spatial dimension of every aspect of credit, useful only in a limited range of sites within the framework of a given trading ring (unless one accepted significant conversion costs) created powerful barriers to entry and a near-total opacity of a given market segment for any outside actor. The logic of economic activity during the early modern period therefore compelled merchants to attempt to join a group of peers constituted as a ring that collectively controlled a segment of the market. Control was established through a negative process, by denying outside agents access to capital, information, and other technical tools needed to participate in the market segment from which they were excluded. This was matched by a positive process that produced powerful social obligations and which I have described here. The bonds between individuals operating within the same segment were, economically speaking, sufficiently strong to impose a minimal unity of action even in the absence of an institutionalized cartel. Eventual transgressions could only occur within commonly accepted limits, and the price of ignoring them could rapidly become prohibitive.

An economy articulated around trading rings controlling the flow of merchandise, credit, and information within segmented markets informed the daily lives and accounting practices of the most advanced merchants of the period. The question remains whether this economy was truly singular and whether one should therefore avoid applying standard economic models in order to understand and describe it. Clearly, such models can be adapted to situations that do not satisfy the microeconomic conditions that they posit, yielding reasonably descriptive and predictive results in macroeconomic terms. With regard to historical analysis, however, this flexibility represents more of a problem than a solution. The ideas of competition or supply and demand do not describe in a historically persuasive way the imperatives faced by the principal economic agents of the early modern period. By focusing on the notions of credit and merchant rings, provided that they are adequately defined, these imperatives become legible. Credit was a qualitative element extending well beyond the domain of accounting to encompass everything that an individual could ask of a group of peers, including not only information, expertise, and, of course, capital, but also political support and social recognition. The trading ring was a specific economic tool articulated around a market segment that needed to be controlled to the fullest possible extent. On the periphery, even a village grocer participated in this economy, attempting to parlay his or her role as an interface with consumers into credit with more important merchants, in the hope of joining and constructing his or her own profitable rings.

The motivations and strategies of participants in this particular world and those involved in the industrial capitalism that gradually came to dominate the 
economy beginning in the mid-nineteenth century can certainly be analyzed in similar ways in terms of profit, maximizing rationality, or the quest for the lowest possible transaction costs. But this unifying vision also limits one's understanding. Can it be argued that when he wrote his accounting treatise in 1736, Mair was attempting to establish a financial position and ensure its evolution, measure its profitability, calculate losses and gains, construct a financial statement, and use the resulting tools to help with decision-making and risk reduction? The answer is yes, if one omits the functional specificities of the economy of his period and the differences they generated with regard to the meanings of certain terms used by Mair that may appear familiar to a contemporary audience. The answer is no, however, if Mair's own practices and those of the other actors of the period are used as the primary reference. When Mair wrote about the "Estate" of the proprietor, he was thinking of a body of credits and debts that were not necessarily generated within the strict framework of mercantile activity and that in any case represented only part of an actor's value-and not even the most important part, since one's most important asset at the time, one's "reputation," was intangible-, which in turn generated "trust" and, hence, "credit." Periodically measuring one's wealth served as a useful indication of where one stood, but nothing more. Similarly, calculating profits and losses initially served to help clarify accounts, by enabling a merchant to extract operating expenses and revenues from them that were not, or were no longer, active within the flow of credit. It was rarely, if ever, a tool for measuring performance. Any efforts to measure performance had meaning only within the framework of a well-defined market segment (for example, specific articles of merchandise), provided that several trading rings were not involved. Ultimately, a balance sheet figured as an assessment of credits and debts more than as a statement of assets and liabilities. With regard to all of these issues, every available source-accounting manuals, descriptions of transactions, and balance sheets-speak to us across the centuries as if with a single voice, reminding us that if we filter them through our own conceptions and economic practices, we will at best scarcely hear them. 